\title{
Impact of Macroeconomic Surprises on Carry Trade Activity
}

\author{
Michael Hutchison \\ Department of Economics, E2 \\ University of California, Santa Cruz \\ Santa Cruz, CA 95064 USA
}

\author{
Vladyslav Sushko* \\ MED, Policy \& Coordination \\ Bank for International Settlements \\ Basel 4002, Switzerland
}

November 2011

\begin{abstract}
Can official news and policy announcements affect foreign exchange speculation? This paper investigates the impact of macroeconomic surprises on risk perceptions of carry traders and the size of their overall positions. Unlike much of the previous literature, we are able to identify a significant impact of macroeconomic surprises on foreign exchange volatility of JPY/USD even at low (daily) frequency. We use information gleaned from risk reversal contracts (tails of the implied returns distribution) during the period when concerns about sharp yen appreciation were particularly high, hence more likely to show up in the price of risk. We also consider a broader set of U.S. and Japanese news than previous work, focusing on the announcements with particularly large surprise components to them. Overall, we find that macroeconomic news is an important determinant of risk reversals during periods of heavy carry trade volume, particularly when the cost of hedging against large yen appreciation is increasing. The results are more supportive of the trade-balance flow channel over portfolio-balance or monetary channel of exchange rate determination during the sample period. Specifically, Japan (U.S.) macro news that worsen (improve) the trade balance generally are associated with less perceived risk of sharp yen appreciation, as reflected in the value of risk reversals. Moreover, there is a close link between risk reversals and non-commercial futures positions. We calculate a substantial effect of macroeconomic news on carry trade activity, with risk reversals (the cost of hedging) as the transmission mechanism.
\end{abstract}

JEL classification: C22, F31, G14

Keywords: Macroeconomic News, Risk Reversals, Foreign Exchange Futures, Carry Trade

\footnotetext{
* The views expressed in this paper are those of the authors and should not necessarily be attributed to the Bank for International Settlements or the Committee on the Global Financial System.
} 
Introduction

One of the consequences of the zero-interest rate policy in Japan was the emergence of massive yen currency carry trade activity where investors borrowed in yen (funding currency) and bought higher-yield assets in other currencies (target or investment currency). Specifically, carry trade is a foreign exchange arbitrage strategy in which an investor borrows in a low interest rate currency and takes a long position in a higher interest rate currency betting that the exchange rate will not change so as to offset the profits made on the yield differential. For example, an investor can fund higher yielding deposits in the U.S. by borrowing from commercial banks in Japan at low interest. This strategy will necessitate a foreign exchange transaction to sell yen for U.S. dollars in order to convert yen liabilities into dollar assets. In addition to issuing liabilities in low-interest currencies, carry trade can be conducted using currency forwards and futures on the margin (Gagnon and Chaboud 2007). For example, a hedge fund could enter a forward contract to sell yen for dollar at some future date. Such carry trade strategies generated persistent excess returns (e.g. Burnside et al., 2007; Darvas, 2009; Hichradl and Wagner, 2010), but also exposed carry traders to substantial currency risk and large losses if the yen were to appreciate substantially (Gyntelberg and Remolona, 2007).

Figure 1 shows the U.S.-Japan interest differential and the JPY/USD exchange rate during 2004-06 when the yen carry trade was at its height. The prolonged low interest policy and weak economy in Japan, during which short-term money market rates were continuously near zero, combined with a strong economy and rising interest rates in the U.S., led to a rising, large and persistent interest differential. The figure also shows that the JPY/USD depreciated on average over this period, but that trend depreciation was interrupted by several episodes of sharp appreciation and considerable volatility. This seeming violation of uncovered interest parity $(\mathrm{UIP})^{1,2}$ allowed profit opportunities (ex post) for carry traders, but the riskiness of this strategy was also exposed during the bouts of large yen appreciation.

One way to hedge against the risk of substantial yen appreciation is to enter into a risk reversal contract. A risk reversal contract is the simultaneous purchase of a deep out-of-money

\footnotetext{
${ }^{1}$ An appreciation of the high yield currency is an example of the forward premium puzzle and the violation of the uncovered interest parity (UIP) well documented by Hansen and Hodrick (1980) and Engel (1996).

${ }^{2}$ Ichiue and Koyama (2011) estimate the UIP regression coefficient as low as -2.79 for the yen.
} 
(OTM) call option and the sale of a deep OTM put option ${ }^{3}$. The holder of the risk reversal is hedging against sharp yen appreciation and accepting (unlikely) downside risk of sharp yen depreciation, taking on a one-sided bet. If yen (funding currency) appreciates sharply, the payoff is positive for the risk reversal. The opposite is true for sharp yen depreciation. Carry traders would lose on this risk reversal contract if the yen depreciates sharply, but this loss is more than offset by gains from holding an open yen carry-trade position. As such, the value of risk reversals are frequently treated as a proxy of expectations about the risk of very large changes in exchange rates ${ }^{4}$. During the "carry trade" period in Japan, when financial institutions were borrowing heavily in yen and investing in assets denominated in U.S. dollar and other currencies, the value of the risk reversal was always negative. This indicates a market hedge against sharp appreciation of the JPY/USD exchange rate.

This paper investigates market perceptions of the risk of large exchange rate movements by using information gleaned from risk reversal contracts and macroeconomic news surprises. ${ }^{5} \mathrm{We}$ focus on the height of the carry trade period in Japan (March 2004 through December 2006), where the sample is delimited at the beginning by the cessation of the Bank of Japan large-scale intervention operations and ends before the financial crisis emerged. Our view is that concerns about sharp yen appreciation were particularly evident during the period of heavy carry trade activity and are more likely to show up in the price of risk.

We are interested in which macro news announcements appear to influence the risk assessments of traders involved in the yen carry trade. Does macroeconomic news explain the hedging behavior of foreign exchange traders and is this important for the carry trade? To investigate this question we focus on "big" news surprises (greater than one standard deviation movements) that are more likely to convey information about the risk of large changes in the exchange rate. To our knowledge, we are the only study that investigates the direct impact of news (other than foreign exchange market intervention) for the value of JPY/USD risk reversals.

\footnotetext{
${ }^{3}$ A risk reversal is a directional bet on (or hedge against) a large price movement constructed by a simultaneous purchase of out-of-money call and sale of out-of-money put option (usually 25 or 10 delta) of the same maturity. The value itself is the implied volatility for the call minus the implied volatility of the put.

${ }^{4}$ Brunnermeier et al. (2009) interpret such persistent UIP violations as a compensation to carry traders for the downside risk of sharp funding currency appreciation.

${ }^{5}$ Evans and Lyons (2008) investigate the impact of macro news on order flow, while Ito and Hashimoto (2010) and Fatum, Hutchison, and Wu (2010) investigate high frequency responses to macro surprises in JPY/USD exchange rate. Galati et al. (2006) and Disyatat and Galati (2007) consider the impact of official foreign exchange market intervention on risk reversals in the JPY/USD market and Czech Koruna - Euro market, respectively.
} 
In our investigation we consider a broad set of news- thirty three sources (18 U.S. series and 15 Japan series) - the choice of which is guided both by theory and previous empirical work in related areas. A critical issue in the yen carry is the particular concern over large yen appreciation, so we explicitly consider the asymmetric impact of news possibly stemming from loss aversion when the cost of hedging yen appreciation is increasing. Finally, we consider the indirect effect of news through the value of risk reversals on the yen carry trade, using (noncommercial) open interest positions in future markets as a proxy for carry trade activity. The investigation of the link between macroeconomic news and futures positions through the riskreversals channels may provide an explanation base on carry trade activity to the finding by Chen and Gau (2010) in that the contribution of futures prices to overall price discovery in foreign exchange markets increases markedly around the times of macroeconomic announcements.

Unlike much of the previous literature, we are able to identify a significant impact of macroeconomic surprises on foreign exchange volatility of JPY/USD even at low (daily) frequency. We use information gleaned from risk reversal contracts (tails of the implied returns distribution) during the period when concerns about sharp yen appreciation were particularly high, hence more likely to show up in the price of risk. Overall, we find that macroeconomic news is an important determinant of risk reversals during periods of heavy carry trade volume, particularly when the cost of hedging against large yen appreciation is increasing. Estimates using predicted values based regression coefficients show that the cumulative impact of macroeconomic surprises can account for more than a third of the total change in risk reversals during particularly dramatic episodes of changing risk perceptions in the JPY/USD market. Moreover, there is a close link between risk reversals and NCMS positions (a proxy for carry trade activity), and this link is borne out in Granger causality tests. Using this metric, we are able to calculate the effect of macroeconomic news on carry trade activity, with risk reversals (the cost of hedging) as the transmission mechanism. Depending on the subsample and calculation method macroeconomic news surprises can translate into more than one third of the total adjustment in yen speculative positions. 
The paper is organized as follows. Section 2 describes the data and institutional features of the carry trade and market for risk reversals. Section 3 presents the main empirical analysis and results. This section establishes a link between macroeconomic surprises and the value of risk reversals which is robust to a number of empirical model specifications. We consider a large variety of news types and, given that risk reversals price the probability of extreme exchange rate fluctuations, we identify large surprises. Section 4 investigates the link between risk reversals and carry-trade activity where, as a proxy for the latter, we use open interest non-commercial short futures positions (NCMS) in yen on the Chicago Mercantile Exchange (NCMS increased from 40,000 to over 160,000 during our sample period). By examining the correlations and through Granger-causality tests we establish a robust link between risk reversals and net NCMS showing that the short positions in yen decline (rise) following an increase (decrease) in the cost of insurance against a substantial yen appreciation. The empirical link between non-commercial futures and risk-reversals may help explain the recent finding by Chen and Gau (2010) that the share of the contribution to the price discovery in the JPY/USD markets of futures rates rises relative to spot rates during the times surrounding the macroeconomic announcements. The Granger-causal relationship between risk reversals and NCMS allows us to obtain an estimate of the impact of macroeconomic news surprises on the risk-sensitive carry trade activity.

\section{Data and Risk Reversals}

\subsection{Institutional Features}

A risk reversal is a directional bet (or hedge) against large price swings. It is a contract long one unit out-of-the-money (OTM) (typically 25-delta ${ }^{6}$ ) FX call option and short one unit OTM FX put option. In other words it is the cost of buying insurance against large foreign currency appreciation, financed by providing insurance against large foreign currency depreciation. The value of a risk reversal is equal to the implied volatility of an out-of-money call minus the implied volatility of an out-of-money put of the same moneyness and maturity. Garman and Kohlhagen (1983) applied the original Black and Scholes (1973) framework to foreign exchange

\footnotetext{
${ }^{6}$ The delta of an FX option measures its sensitivity to the spot exchange rate. The strike price of a 25-delta option is far enough from the spot price such that the option premium exhibits only a 0.25 correlation with changes in the strike price.
} 
options. We following Galati and Humpage (2006) with the following representation of a price of a European foreign exchange call option:

$$
C(X, \sigma)=\frac{1}{(1+i) T}\left(F \cdot \Phi\left(d_{1}(X, \sigma)\right)-X \cdot \Phi\left(d_{2}(X, \sigma)\right)\right)
$$

where,

$$
d_{1}=\frac{\ln (F / X)+\left(\sigma^{2} / 2\right) T}{\sigma \sqrt{T}}, d_{2}=d_{1}-\sigma \sqrt{T}
$$

$X$ is the strike price, $F=e^{\left(i-i^{*}\right)} S$ represent the forward rate, $i$ and $i^{*}$ are domestic and foreign interest rates, $S$ is the spot exchange rate and $\Phi$ is the cumulative distribution of a standard normal. An option's delta represent is sensitivity to the changes in the exercise price. Risk reversals are constructed from out-of-money options with only $25 \%$ sensitivity to changes in the strike price. Then the call price has the following property:

$$
\frac{\partial C(X, \sigma)}{\partial X}=0.25
$$

Finally, a 25-delta risk reversal is the difference in the implied volatility of a 25-delta call and put option:

$$
R R 25=\sigma_{c}^{25 \delta}-\sigma_{p}^{25 \delta}
$$

Under a symmetric risk-neutral distribution the value of risk reversal should be zero since both OTM call and put will have the same probability of landing at-the-money by the expiration date. Therefore, risk reversals only take on non-zero values if the risk-neutral distribution of foreign exchange returns is skewed, their value conveying the combined effect of expected skewness and skewness risk premium. Negative values of risk reversals imply that out-of-money dollar puts have a higher probability of being exercised than out-of-money dollar calls indicating a market hedge against large yen appreciation (U.S. dollar depreciation).

Jain and Stafford (2006) find that yen rallies, carry trade unwinding, and bouts of risk aversion are correlated. Hence, risk reversals likely capture risk appetites of carry traders during the times of high cost of insurance against yen appreciation. Whether risk reversals are forward looking is still uncertain. Jain and Stafford (2006) find that sharp movements in spot are usually followed by risk reversal overvaluation as risk premium increases and implied skew in the following period is higher than the realized skewness of the return distribution. Examining data 
at daily frequency, Chaboud and Gagnon (2007) argue that during periods of high volatility movements in risk reversals postdate movements in exchange rates. At weekly frequency Carr and $\mathrm{Wu}$ (2007) find that JPY/USD and GBP/USD returns show positive correlations with changes in risk reversals. Farhi et al. (2009) find that monthly changes in nominal interest rates and risk reversals exhibit strong contemporaneous link. The same authors also find some evidence of exchange rate excess returns (relative to UIP) predictability with risk reversals very high levels of risk reversals may predict currency appreciation.

Unlike the implied skewness of at-the-money options, risk reversals provide potentially useful information on market pricing of extremely large events ${ }^{7}$. Farhi and Gabaix (2008) formulate a general equilibrium model in which they show that under certain conditions risk reversals depict the difference in the resilience of the two country's export sector productivities to aggregate shocks.

We are aware of two studies that have investigated the empirical links between risk reversals ${ }^{8}$ and official foreign exchange market intervention, using macroeconomic news in one case as control variables. Galati et al. (2006) estimate the effect of Japanese foreign exchange market intervention on the value of JPY/USD risk reversals along with other measures of dispersion in exchange rate expectations. ${ }^{9}$ They consider daily data over January 1996 - November 2005 and find weak evidence that intervention operations impact risk reversals. Disyatat and Galati (2007) study the impact of official intervention on the value of risk reversals in the Czech Koruna Euro, using daily data over September 2001 to September 2002. They also find that intervention has a limited impact on risk reversals, but that macroeconomic news is not significant. (They consider several measures of price, output and unemployment surprises for the Czech Republic and Germany).

\footnotetext{
${ }^{7}$ Risk reversals are also used indirectly along with other option derivatives to derive higher moments of risk neutral distributions. Galati et al. (2005) and Morel and Teiletche (2008) study the relationship between official interventions in foreign exchange and market uncertainty. They use FX strangle and risk reversal prices to recover option implied higher moments of the risk-neutral FX return distribution.

${ }^{8}$ Several related studies including Beber and Brandt (2006), and Aijo (2008) investigate the impact of macroeconomic surprises on options implied higher moments, including option implied skewness, while Lahaye et al. (2010) study the effects macro announcements on jump components in realized volatility.

${ }^{9}$ Galati et al. (2005) consider the effect of intervention and macroeconomic news on several measures of expectations regarding exchange rate movements, one of which (skewness) is derived from the value of risk reversals.
} 


\subsection{Data}

We obtain daily data on 1-month and 1-year 25-delta risk reversals from Bloomberg. We confine our sample to the tranquil period of active carry trade after the last episode Japanese official interventions that ended in March 2004 and before the beginnings of the emerging financial crisis in the middle of 2007. In all we end up with 715 daily observations excluding weekends from 03/18/2004 through 12/31/2006.

In terms of macroeconomic news, we seek to identify variables that may influence the risk perceptions of carry traders regarding the likelihood of large exchange rate movements (as gleaned from risk reversal contracts). Although there are various theoretical exchange rate models linking macro news surprises to exchange rate movements, there is no consensus in the literature over which drivers are most important in theory or empirical analysis. Two broad exchange rate theoretical paradigms may be identified-(1) flow models that emphasize the impact of various economic drivers on the trade balance and thereby the exchange rate and (2) stock models that emphasize the impact of various economic drivers on asset prices and thereby the exchange rate (e.g. portfolio balance models and monetary models of exchange rate determination). The academic profession generally prefers the asset-market approach to exchange rate determination, while practitioners frequently refer to the trade balance/exchange rate nexus as important in practice. Moreover, many economic drivers may enter in either theoretical paradigm but frequently with different directions of causal influence. For example, strong GDP growth may be an indicator of stronger money demand and lead to a currency appreciation in the asset model, or an indicator of worsening trade balance and currency depreciation in the flow model.

Unfortunately, the empirical literature is not able to fully distinguish which model explains exchange rate movements best in practice. We therefore cast the net widely and include in our set of explanatory variables an array of macro news, guided partly by those having demonstrated significant explanatory power in related empirical work and partly by data availability. As discussed in the next section, it turns out that our results - in terms of the signs of the coefficients-- are most easily economically interpreted in the context of a trade-balance flow model of exchange rate determination, i.e. factors that tend to improve the Japanese (U.S.) trade 
balance appear to decrease the value of risk reversals, implying a rise in the expected likelihood of large yen (USD) appreciation.

We begin by choosing Japanese news variables that are comparable to U.S. news variables found to be statistically in the Andersen et al. (2003) investigation of exchange rates and other asset prices. ${ }^{10}$ The inclusion of most of these variables may be justified by both the flow and asset models of exchange rates. We also consider several uniquely Japanese news items that are considered to be particularly important as indictors for the strength of Japan's economy, e.g. surprises regarding the Bank of Japan's TANKAN survey variables. ${ }^{11}$ In addition, we include on our list news surprises regarding U.S. consumer and producer price indices, variables that are especially important in the monetary approach to exchange rate determination. In total, the data includes announcements and survey expectations regarding 15 types of Japanese macro news and 18 types of U.S. macro news. The Japanese news variables are GDP (quarterly), Industrial Production, Capacity Utilization, Construction Orders, Overall Spending, Large Retail Sales, Trade Balance, Current Account, Retail Trade, Consumer Price Index, Consumer Confidence Index, TANKAN Large Manufacturing Index, TANKAN Non-Manufacturing Index, Leading Economic Index, and Monetary Base. The U.S. news variables are GDP, Non-Farm Payroll Employment, Industrial Production, Capacity Utilization, Personal Income, Consumer Credit, Consumer Spending, New Home Sales, Durable Goods Orders, Factory Orders, Business Inventories, Trade Balance, Producer Price Index, Consumer Price Index, Consumer Confidence Index, NAPM Index, Housing Starts, and Index of Leading Indicators.

Consistent with the recent literature on exchange rates and news, for each of the macroeconomic announcements in our data we follow the broader literature in defining news surprises as the difference between the macroeconomic announcement and the preceding survey

\footnotetext{
${ }^{10}$ This selection criteria follows Fatum, Hutchison and Wu (2010). Japanese macro announcements are from Bloomberg News Service and are also available from the data banks of the Bank of Japan and the Japanese Cabinet Office. Andersen et al. (2003) consider U.S. and German macro news in their study of exchange rates, not Japanese news.

${ }^{11}$ The Bank of Japan website at www.boj.or.jp/en/theme/research/stat/tk/index.htm provides details (in English) regarding the TANKAN survey variables.
} 
expectation of that announcement. Subsequently, we standardize each news surprise series in order to allow for a comparison of the relative influences of different types of news. ${ }^{12}$

In addition we construct a daily series of interest rate spread between U.S. and Japan as the difference between the effective federal funds rate and Japan's uncollateralized overnight call rate. Both are publicly avaiable from the Federal Reserve Bank of New York and Bank of Japan respectively.

We obtain the weekly futures positions data from the Commodity Futures Trading Commission (CFTC)'s Commitment of Traders (COT) report which is released at weekly frequency and reflects positions at the close of every business Tuesday. Among other variables, the OTC reports include weekly times-series of non-commercial trader long and short positions in yen as a percentage of total open interest. The CFTC defines open interest as the sum total of all futures contracts not yet offset by transaction, delivery or exercise. We construct the measure of CME net non-commercial short positions (NCMS) as a percentage of open interest (\% O.I.) by subtracting non-commercial long from non-commercial short positions divided by total open interest in yen futures.

2. Empirical Results: Macro News and Risk Reversals

\subsection{Preliminaries}

The upper panel of Table 1 reports summary statistics for the 1-month and 1-year risk reversal series in levels and in first differences. The maximum and minimum are $(-0.05,-2.45)$ and $(-0.725,-2.75)$ for 1-month and 1-year risk reversals respectively indicating that both series have remained negative throughout the sample period consistent with market hedge against sharp yen appreciation.

\footnotetext{
${ }^{12}$ A standardized news surprise is given by the unexpected component of the macroeconomic announcement divided by the associated sample standard deviation. Let $A_{q, t}$ denote the value of a given macroeconomic fundamental q, announced at time (minute) t. Let $E_{q, t}$ refer to the median value of the preceding market expectations for the given fundamental at announcement time t, and let $\hat{\sigma}_{q}$ denote the sample standard deviation of all the surprise components associated with fundamental q. The standardized surprise of macroeconomic fundamental q announced at time $\mathrm{t}$ is then defined as $S_{q, t}=\left(A_{q, t}-E_{q, t}\right) / \hat{\sigma}_{q}$.
} 
Augmented Dickey Fuller (ADF) and Phillips-Peron unit root tests are shown in the lower panel of Table 1. These tests indicate that the log levels were not stationary. The null hypothesis is that there exists a unit root. The first column shows the unit root test on the value of a one-year 25 delta risk reversal. The second column is the corresponding tests on first differences of the values. Both tests fail to reject the null hypothesis of a unit root in levels, but reject the null in first differences by a large margin (greater than $99 \%$ level of confidence). We therefore proceed to estimate our empirical model with the dependent variable in first difference form.

\subsection{Estimation Results}

Tables 2 and 3 report the results. We focus in our formal empirical analysis on one-year risk reversals, the longer maturity options, in order to capture the hedging horizons of carry traders $^{13}$. Table 2 shows the baseline results where the regressions are estimated using OLS and all the macroeconomic surprises are included in the data set, i.e. we do not drop "small" surprises from the sample. Table 3 focuses on whether "large" changes affect the value of risk reversals, as would be expected since risk reversals reflect the risk of very large exchange rate changes. We use two criteria to select "large" surprises. The first approach is to consider only surprises outside "narrow bounds," i.e. exclude all surprises less than one standard deviation from the series specific mean value. The standard deviation is calculated based on all observations of the surprise variables, including days with no surprises. The second approach, which denote as "wide bounds," is a stricter criteria whereby the standard deviation is calculated on non-zero observations only, thus effectively making the exclusion bounds wider. The results reported in the two tables are similar and most of the discussion will focus on our preferred equation reported in Table 3. Only the significant coefficients are reported for brevity. Complete regression results are reported in the appendix tables.

The two panels of Table 2 include the same news surprises, while the right-hand-side panel also controls for the exchange rate and the interest rate differential. The point estimates for those coefficient values which are significant are virtually identical in the two regressions, but controlling for exchange rates and the interest rate differential (right panel) give substantially

\footnotetext{
${ }^{13}$ The one-month results are available upon request. These are generally weaker than the one-year results, consistent with the view that the carry trader horizon is for hedges of longer maturity.
} 
higher explanatory power (higher $\mathrm{R}^{2}$ ) and a better fit of the equation based on a large (absolute value) AIC statistic. Two U.S. news surprises (GDP and Consumer Credit) and three Japanese news surprises are significant (Trade Balance, Consumer Confidence and Overall Household Spending), in addition to the exchange rate and interest rate differential.

How may the significant estimates be interpreted economically? The signs are consistent with the trade balance/flow model of exchange rate determination. Recall that the value of risk reversals remained negative throughout the carry trade sample we are investigating, indicating a market hedge against sharp yen appreciation. A negative (positive) coefficient value indicates higher (lower) risk of large yen appreciation. (A more negative value of risk reversals indicates greater combined effect of expected probability of sudden yen appreciation and of the associated risk premium.) U.S. trade deficits are associated with higher GDP growth and stronger U.S. consumer credit, leading to a lower value of risk reversals - the perceived risk of sharp dollar depreciation against the yen rises. News of improvement in the Japanese trade balance reduces the value of risk reversals, increasing the perceived likelihood of sharp yen appreciation, while rising Japanese Consumer Confidence Index and Overall Household Spending reduces the Japanese trade balance, in turn increasing the value of risk reversals and leading to less risk of major yen appreciation

The value of including the exchange rate and interest rate differential is evident from the estimates in Table 2, so we include these variables in Table 3 where we focus on "large" news surprises. The left-hand-side panel is estimated using OLS and the right-hand-side is estimated using an ARMA $(4,4)$ process, for both "large" surprise selection criteria. In particular, closer analysis of the errors of the initial estimation suggested both $\mathrm{AR}(4)$ and MA(4) terms were appropriate—-based on a significant lag in the autocorrelation function and partial autocorrelation function, respectively - in the estimation. This model was chosen, relative to a simple OLS estimation, given the Akaike information criteria. ${ }^{14}$

\footnotetext{
${ }^{14}$ These results are omitted for brevity but are available from the authors upon request. Monday and Friday dummies were also included in the initial estimation but were not statistically significant. Various values of $\mathrm{p}, \mathrm{q}$ in the ARMA (p,q) process were considered and the $p=4$ and $q=4$ were selected based on the AIC criteria.
} 
The right-hand-side panel of Table 3 shows that the same explanatory variables remain significant (U.S. GDP and Consumer Credit and Japan's Trade Balance, Consumer Confidence and Overall Household Spending) when only "large" surprises are considered. In addition, U.S. Personal Income and Japan's TANKAN Non-Manufacturing Index are highly significant under the "wide bounds" selection criteria. In all, three U.S. macro news surprises and four Japanese macro news surprises have a statistically significant impact on the value of risk reversals during our sample period.

The standardization of the macro news surprises allows a comparison of the relative sizes of the coefficients. Consumer Credit has the highest coefficient in absolute value among U.S. surprises at -7.0 compared to -3.9 for U.S. GDP and 1.2 for Personal Income. Among the Japanese macro surprises Trade Balance has the highest coefficient in absolute value of -6.4 followed by Overall Household Spending with 4.8 .

\subsection{Conditional Regressions}

Next we examine the possibility that surprise macroeconomic announcements may have an asymmetric impact on risk reversals during periods of increasing risk of a large yen appreciation compared to periods of decreasing risk of a large yen appreciation. We construct an increasingrisk-dummy variable that takes on a value of 1 on day when risk reversals rise in absolute value and a value of 0 otherwise. Then we repeat the regression of LARGE macroeconomic surprise announcements using the ARMA $(4,4)$ specification interacting each news surprise with the lagged rising-risk dummy. Table 4 shows the results for both "narrow bounds" and "wide bounds" regressions. An estimate is missing (indicated with "“-") if no LARGE surprise announcement for a particular news type was preceded by an increase in the absolute value of risk reversals during our sample period.

The regression results in Table 4 indicate that the set of significant macroeconomic surprises, when an announcement is preceded with an increase in the cost of hedging yen appreciation risk, is not the same as the unconditional specification. Moreover, under the stricter "wide bounds" selection criteria for LARGE surprises, more types of macroeconomic news surprises have a statistically significant impact on risk reversals. The difference is especially stark for news emanating from the U.S. Both conditional regressions exhibit higher R-squared, Durbin-Watson, 
and Akaike information criterion than unconditional regressions reported in Table 2 and Table 3 indicating that most of the explanatory power of macroeconomic news surprises is higher during periods of increasing risk aversion.

Focusing on the "narrow bounds" regression (left panel of Table 4) first, different U.S. news surprises are significant when conditioning on periods of rising risk aversion towards yen appreciation. A positive surprise on Capacity Utilization and Housing Starts tend to increase the value of risk reversals (reduce the perceived risk of yen appreciation) in times when that risk was rising. In terms of the exchange rate/balance-of-payments nexus, a rise in these variables may indicate greater U.S. demand for domestic intermediate goods relative to Japanese imports. This represents a reduced trade surplus of Japan and may lower the risk of sharp yen appreciation.

Among Japanese macroeconomic news, large surprises to the Leading Economic Index, quarterly GDP, and Retail Trade exhibit significant negative coefficients while Overall Household Spending remains positive and significant as was also the case in the unconditional regressions.

Next we focus on the "wide bounds" regression (right panel of Table 4). Under this specification 8 U.S macro and 5 Japanese macro surprise announcements are statistically significant. Most notably, U.S. and Japanese Trade Balance surprises have the largest coefficients in absolute value and are both statistically significant at the $1 \%$ level. Consistent with the exchange rate/balance-of-payment nexus interpretation a surprise improvement in U.S. Trade Balance is also associated with a reduction in the absolute value of risk reversals while the surprise improvement in Japan's Trade balance makes sharp yen appreciation more likely to increase risk reversals in absolute value.

Among other U.S. news, the coefficients on Capacity Utilization and Housing starts remain positive and the coefficient on Personal Income is positive and significant as was also the case in the unconditional regressions. On the other hand, higher values of Consumer Credit, Consumer Price Index, and Index of Leading Indicators increase the perceived risk of yen appreciation (reduce the value of risk reversals), with the latter two variables having an impact only under the current specification conditioning on the environment of rising risk aversion. As for the rest of 
the Japanese macroeconomic surprises, a positive surprise to TANKAN large manufacturing index and construction orders mitigate the perceived risk of yen appreciation whereas large surprises to Japanese Retail Trade and Consumer Price Index are associated with a further increase in the absolute value of risk reversals.

\subsection{Assessment of Economic Impact of Macro Surprises on Risk Reversals}

We conduct a rough assessment of the cumulative impact of macroeconomic surprises on the value of risk reversals. In this section and the next, we focus on two subsamples of particularly dramatic changes in the value of risk reversals. The first period, 01/07/2005 through 03/13/2006, corresponds to a substantive reduction in the absolute value of risk reversals from about -2.4 to 1.0. The second, 04/12/2006 through 05/172006, corresponds to a substantial increase in the absolute value of risk reversals from -1.0 to -2.0. The impact of each type of macro news is calculated by multiplying the regression coefficient by the value of the standardized surprise.

Table 5 shows the results for the two subsamples. The first two columns show the cumulative impact from surprise macro announcements for the first subsample, using both the "narrow band" for upper bound and the "wide band" for the lower bound regressions from Table 3. The cumulative impact of macroeconomic surprises ranges from 0.32 to 0.37 , accounting for $25-30 \%$ of the total change in the value of risk reversals over this episode. In particular, the net negative GDP and consumer credit news in the U.S., combined with negative trade balance news in Japan, led to a sharp reduction in the perceived risk of large yen appreciation. Recall that the $\mathrm{R}^{2}$ in the baseline regression not controlling for exchange rate or interest rate was approximately 0.03 indicating that over the entire sample period surprise macro announcements explain approximately $3 \%$ of the variation in the value of risk reversals. However, focusing on a subsample of dramatic decline in the market value of risk we see that macro surprise announcements can account for over $30 \%$ of the cumulative change in the value of risk reversals.

The third and fourth columns of Table 5 report the cumulative impact for the second subsample when the perceived risk of major yen appreciation jumped markedly. The rise in absolute value of risk reversals (rise in perceived risk of large yen appreciation) during this episode is associated with several surprise announcements, namely a sharp unanticipated rise in 
the Japanese Trade Balance and fall in Japanese Household Spending. These announcements accounted for approximately $10 \%$ of the total rise in absolute value of risk reversals during this episode.

Figure 2 depicts the results graphically in terms of the volatility smile for the two subsamples: 01/07/2005 through 03/13/2006 (top panel) and 04/12/2006 through 05/172006 (bottom panel). The asymmetric "volatility smirk" indicates a thick left tail (negative skewness) of return distribution. The solid line is constructed based on option implied volatility (historical options data) while the two dashed line represent counterfactual volatility distribution based on the results reported in Table 5. During the first subsample, the impact of the negative growth and consumption data from the U.S. combined with negative trade balance news in Japan effectively reduced the negative skewness in the market expectation of JPY/USD returns. The opposite is true of the second subsample (bottom panel), where sudden rise in Japan's trade balance and fall in household spending made sharp yen appreciation more likely, thus raising implied volatility curve in the left tail area of returns distribution.

\section{Link to Carry Trade Activity}

Despite the well-documented profitability of carry trade activity, aggregate flow volumes are difficult to measure because of diverse carry trade strategies ${ }^{15}$ and data limitations. Following Klitgaard and Weir (2004), Galati et al. (2007) and Brunnermeier et al. (2009) we proxy for carry trade activity with futures positions of non-commercial traders on the Chicago Mercantile Exchange (CME), which is the largest exchange for foreign exchange futures by volume ${ }^{16}$. The Commodity Futures Trading Commission (CFTC) usually releases its Commitments of Traders report (COT) on Fridays after the bell, but it reflects the position at the close of previous business Tuesday. CFTC classifies traders as non-commercial if they have no foreign exchange exposure to hedge and therefore presumably trade to make profit ${ }^{17}$. These traders on average

\footnotetext{
${ }^{15}$ For instance Hattori and Shin (2009) argue that carry trade can be accomplished through inter-office loans of multinational investment banks.

${ }^{16}$ Galati et al. (2007) also examine the currency denominations of international assets and liabilities of commercial banks available to the Bank of International Settlements (BIS). Focusing on Japan, Gagnon and Chaboud (2007) trace the balance sheets of not only the banking sector, but also Japan's official sector and private non-banking sector.

${ }^{17}$ A trader is classified as "commercial" or "non-commercial" by filing the Statement of Reporting Trader
} 
hold approximately 20 percent of total open interest positions in major currencies (Sun (2010)). While CME non-commercial futures can only serve as a proxy for the broader yen carry trade, Cecchetti et al. (2010) show that this metric shows close association to a novel BIS measure of carry trade activity based on the BIS banking statistics, foreign exchange swap data, and stock of yen-denominated international bonds. As a way to check the consistency of CME noncommercial short positions in yen with the broader carry trade Figure 3 plots the time series of non-commercial short positions and a simple rate of return to carry trade (following Hochradl and Wagner (2010)):

$$
C R_{t+k}=\left(1+i_{k, t}^{U S}\right) S_{t+k} / S_{t}-\left(1+i_{k, t}^{J P}\right)
$$

where $i_{k, t}$ denote the effective k-period deposit rates available in Japan and U.S. at a given Tuesday of the same week, $t$. We use 1-month deposit rates. This trend is consistent with the expected behavior of carry traders increasingly going short Yen and long USD during the period of rising ex-ante returns to carry trade.

Figure 4 shows the time-series of net non-commercial short positions (NCMS) as percentage of total open interest (\% O.I) (left) against 1-year risk reversals (right), where the frequency of 1-year risk reversals has been converted from daily to weekly (Tuesdays of each week to conform with NCMS data). The series exhibit co-movement indicating that an increase in risk reversals towards smaller negative value (lower cost of insurance against Yen appreciation) is associated with an increase in speculative Yen short positions as proxied by CME non-commercial futures. The pair wise correlations between the weekly changes in noncommercial futures and weekly changes in 1-month and 1-year risk reversals are 0.58 and 0.73 , respectively. We conduct Granger-causality tests to examine whether risk reversals lead (predict) speculative futures positions or vice-versa:

$$
\Delta N C M_{t}=\sum_{j=1}^{2} \alpha_{j} \Delta N C M_{t-j}+\sum_{j=1}^{2} \beta_{t-j} \Delta R R_{t-j}+\sum_{j=1}^{2} \delta_{t}{ }_{j} \Delta r_{t-j}+\mathcal{E}_{t}
$$

(CFTC Form 40). The CFTC staff may re-classify the trader if they possess additional information about the trader's use of the futures market. Furthermore, each trader receives a separate classification for each commodity depending on the traders' use of each market. In 2009 the CFTC began published the Disaggregated COT with more detailed trader classifications. Its own historical comparison between the two reports finds that historically the "noncommercial" category included professional money managers (such as hedge funds and commodity trading advisers) and other "speculative" traders while the "commercial" category has included producers, merchants, processors, and swap dealers who use futures markets to offset risks incurred in over-the-counter markets. For further details see http://www.cftc.gov/MarketReports/CommitmentsofTraders/. 


$$
\Delta R R_{t}=\sum_{j=1}^{2} \alpha_{j} \Delta N C M_{t-j}+\sum_{j=1}^{2} \beta_{t}-{ }_{j} \Delta R R_{t}-j+\sum_{j=1}^{2} \delta_{-j} \Delta r_{t}-j+\mathcal{E}_{t}
$$

The Granger causality results, reported in Table 6, indicate that risk reversals lead (Granger-cause) net non-commercial yen short positions but that positions do not lead risk reversals. The results are robust to the inclusion of the lagged (log changes) exchange rate as a control, indicating that past values of risk reversals have informational content in excess of that of the lagged exchange rate returns. While all statistics are significant at the $1 \%$ level, the teststatistics are higher for 1-year risk reversals. For example, the cumulative effect (sum of the coefficients) of the 2-lag specification for 1-year risk reversals controlling for the exchange rate, is 30.38. A 100 basis point decrease in the absolute value of risk reversals over a two-week period is followed by a $30.4 \%$ increase in the net NCMS as a fraction of total open interest potions, i.e. a sharp reduction in the perceived risk of large yen appreciation leads to substantially more carry trade activity. Overall, Granger-causality results indicate that risk reversals convey important information on currency risk in excess of the exchange rate itself that is taken into account by non-commercial traders when deciding to take on an open interest futures position. Our findings are consistent with Brunnermeier et al. (2009) who find that the value of risk reversals tends to decline together with carry trade activity when financial markets in the U.S. become unstable suggesting that it is mainly carry traders who rely on risk reversals to ensure their portfolios.

A simple "back of the envelope" calculation measuring the impact of macroeconomic surprises emanating from U.S. and Japan on carry trade activity transmitted during the two episodes of wide swings in risk reversals (a reduction in perceived risk and a rise in perceived risk) discussed in the previous section is informative. As Figure 4 shows, the first episode (1/07/2005 through 03/13/2006), when perceived risk declined (-2.5 to -1.0), was accompanied by a switch from a $20 \%$ net long position to a $40 \%$ net short open position of non-commercial traders, indicating a sharp rise in carry trade activity. The second episode (04/12/2006 through 05/17/2006), when perceived risk increased sharply (-1.0 to -2.0), was accompanied by a large unwinding of short yen open positions - a switch form a $30 \%$ net short position to a $10 \%$ net long position for non-commercial traders. 
The cumulative impact of news surprises on risk reversals is multiplied by the sum of the coefficients on $\Delta R R_{t-j}$ in the Granger-causality equation (7) in Table 6. Table 7 shows the results. The first column of each panel corresponds to the conservative estimate obtained by multiplying the cumulative impact of macro surprises in excess of "wide bands" by the coefficient on $\Delta R R_{t-j}$ in the specification of (7) with 1-lag. The second column yields a higher estimate by multiplying the cumulative impact of macro surprises in excess of "narrow bands" by the sum of the coefficients in the 2-lag Granger causality specification in equation (7).

Based on these calculations, during the first episode U.S. GDP and Consumer Credit surprises had the effect of increasing net NCMS share of total open interest by 2.9 and 6.0 percentage points, respectively, while Japan's Trade Balance surprises accounted for another 2.8 percentage point rise. In total, our estimates suggest that macroeconomic surprises account for $38 \%$ (11.2 percentage points) of the rise in NCMS positions as a share of total open interest in the first episode. During the second episode, the fall in NCMS positions is mainly attributable to Japanese news. Japan's trade balance contributing about -1.7 percentage points to the reduction in speculative positions on CME, while Japan's Overall Household Spending and Japan's Consumer Confidence surprises contributed around -0.9 and -0.3 percentage points, respectively. Overall, macroeconomic surprises emanating from U.S. and Japan accounted about 10\% (-2.67 percentage points) of the fall in NCMS positions during this episode.

\section{Conclusion}

This paper investigates market perceptions of the risk of large exchange rate movements by using information gleaned from risk reversal contracts and macroeconomic news. We focus on the height of the carry trade period in Japan (March 2004 through December 2006), where the sample is delimited at the beginning by the cessation of the Bank of Japan large-scale intervention operations and ends before the financial crisis emerged. Concerns about sharp yen appreciation were particularly evident during the period of heavy carry trade activity and are more likely to show up in the price of risk.

We focus on "big" news surprises (greater than one standard deviation movements) that are more likely to convey information about the risk of large changes in the exchange rate, and consider a broad set of news - thirty three sources (18 U.S. series and 15 Japan series) -- and the 
investigate the direct impact of news other than intervention for the value of JPY/USD yen risk reversals. We also consider the effect of the value of risk reversals on the yen carry trade, using (non-commercial) open interest positions in future markets as a proxy for carry trade activity.

Overall, we find that macroeconomic news is an important determinant of risk reversals during periods of heavy carry trade volume. The results are most intuitively interpreted in the context of joint trade balance/exchange rate model. Macro news from the U.S. that increases the size of the U.S. trade deficit (e.g. high GDP growth and U.S. consumer credit) generally reduce the value of risk reversals, and increase the perceived risk of sharp dollar depreciation against the yen. Symmetrically, news of an improvement in the Japanese trade balance reduces the value of risk reversals and increases the perceived likelihood of sharp yen appreciation, while factors that lead to a worsening Japanese trade balance (e.g. rising Japanese Consumer Confidence Index and Overall Household Spending) increase the value of risk reversals, indicating less risk of major yen appreciation

In addition, we find that is a close link between risk reversals and net non-commercial futures positions (a proxy for carry trade activity), and this link is borne out in Granger causality tests. Using this metric, we are able to calculate the effect of macroeconomic news on carry trade activity, with risk reversals (the cost of hedging) as the transmission mechanism. Depending on the subsample and calculation method, macroeconomic news surprises can translate into more than one third of the total adjustment in yen speculative positions. 


\section{$\underline{\text { References }}$}

Aijo, J. (2008), "Impact of US and UK macroeconomic news announcements on the return distribution implied by ftse-100 index options", International Review of Financial Analysis, Vol. 17, pp. 242-258.

Andersen, T. G., Bollerslev, T., Diebold, F. X. and Vega, C. (2003), "Micro effects of macro announcements: Real-time price discovery in foreign exchange", American Economic Review, Vol. 93, pp. 38-62.

Beber, A. and Brandt, M. W. (2006), "The effect of macroeconomic news on beliefs and preferences: Evidence from the options market", Journal of Monetary Economics, Vol. 53, pp. 1997 - 2039.

Black, F. and Scholes, M. S. (1973), "The pricing of options and corporate liabilities", Journal of Political Economy, Vol. 81, pp. 637-54.

Brunnermeier, M. K., Nagel, S. and Pedersen, L. H. (2009), "Carry trades and currency crashes", NBER Macroeconomics Annual, Vol. 23, pp. 313-348.

Burnside, C., Eichenbaum, M. and Rebelo, S. (2007), “The returns to currency speculation in emerging markets", American Economic Review, Vol. 97, pp. 333-338.

Carr, P. and Wu, L. (2007), "Stochastic skew in currency options", Journal of Financial Economics, Vol. 86, pp. 213-247.

Cecchetti, S. G., Fender, I., McGuire, P. (2010) “Toward a global risk map”, BIS Working Papers, no 309, May.

Chen, Y.-L. and Gau, Y.-F. (2010), "News announcements and price discovery in foreign exchange spot and futures markets", Journal of Banking \& Finance, Vol. 34, pp. 1628 -1636.

Darvas, Z. (2009), "Leveraged carry trade portfolios", Journal of Banking \& Finance, Vol. 33, pp. 944-957.

Disyatat, P. and Galati, G. (2007), "The effectiveness of foreign exchange intervention in emerging market countries: Evidence from the Czech koruna", Journal of International Money and Finance, Vol. 26, pp. 383-402.

Engel, C. (1996), "The forward discount anomaly and the risk premium: A survey of recent evidence", Journal of Empirical Finance, Vol. 3, pp. 123-192.

Evans, M. D. and Lyons, R. K. (2008), "How is macro news transmitted to exchange rates?", Journal of Financial Economics, Vol. 88, pp. 26-50.

Farhi, E., Fraiberger, S. P., Gabaix, X., Ranciere, R. and Verdelhan, A. (2009), Crash risk in currency markets, NBER Working Papers 15062, National Bureau of Economic Research, Inc. 
Farhi, E. and Gabaix, X. (2008), Rare disasters and exchange rates, NBER Working Papers 13805, National Bureau of Economic Research, Inc.

Fatum, R., Hutchison, M. M. and Wu, T. (2010), “Asymmetries and state dependence: The impact of macro surprises on intraday exchange rates," Federal Reserve Bank of Dallas Globalization and Monetary Policy Institute Working Paper No. 49.

Gagnon, J. E. and Chaboud, A. P. (2007), What can the data tell us about carry trades in Japanese yen?, International Finance Discussion Papers No. 899, Board of Governors of the Federal Reserve System

Galati, G., Heath, A. and McGuire, P. (2007), "Evidence of carry trade activity", BIS Quarterly Review.

Galati, G., Higgins, P., Humpage, O. and Melick, W. (2007), “Option prices, exchange market intervention, and the higher moment expectations channel: a user's guide", International Journal of Finance \& Economics, Vol. 12, pp. 225-247.

Galati, G., Melick, W. and Micu, M. (2005), "Foreign exchange market intervention and expectations: The yen/dollar exchange rate", Journal of International Money and Finance, Vol. 24, pp. 982-1011.

Garman, M. B. and Kohlhagen, S. W. (1983), "Foreign currency option values", Journal of International Money and Finance, Vol. 2, pp. 231-237.

Gyntelberg, J. and Remolona, E. M. (2007), "Risk in carry trades: a look at target currencies in asia and the paciffc", BIS Quarterly Review.

Hansen, L. P. and Hodrick, R. J. (1980), "Forward exchange rates as optimal predictors of future spot rates: An econometric analysis", Journal of Political Economy, Vol. 88, pp. 829-53.

Hashimoto, Y. and Ito, T. (2010), "Effects of Japanese macroeconomic announcements on the Dollar/Yen exchange rate: High-resolution picture," Journal of Japanese and International Economies, Vol. 24 (3), pp. 334-354

Hattori, M. and Shin, H. S. (2009), "Yen carry trade and the subprime crisis", IMF Staff Papers, Vol. 56, pp. 384-409.

Hochradl, M. and Wagner, C. (2010), "Trading the forward bias: Are there limits to speculation?", Journal of International Money and Finance, Vol. 29, pp. 423 - 441.

Ichiue, H. and Koyama, K. (2011), "Regime switches in exchange rate volatility and uncovered interest rate parity," Journal of International Money and Finance, Vol. 30 (7), pp. 1436-1450. 
Jain, A. and Stafford, M. (2006), DB guide to risk reversals, Global markets; FX Relative Value, Deutsche Bank.

Klitgaard, T. and Weir, L. (2004), "Exchange rate changes and net positions of speculators in the futures market", Economic Policy Review Vol. 10 (1), pp. 17-28.

Lahaye, J., Laurent, S. and Neely, C. J. (2010), "Jumps, cojumps and macro announcements", Journal of Applied Econometrics, forthcoming

Morel, C. and Teletche, J. (2008), "Do interventions in foreign exchange markets modify investors' expectations? The experience of Japan between 1992 and 2004", Journal of Empirical Finance, Vol. 15, pp. 211-231.

Sun, Y. (2009), Open interest positions and foreign exchange futures price prediction, an application of TVTP Markov Switching Model, UCSC Working Paper. 
Table 1: Summary statistics and unit root tests for risk reversal series

\begin{tabular}{|c|c|c|c|c|}
\hline & \multicolumn{2}{|r|}{ 1-month } & \multicolumn{2}{|r|}{ 1-year } \\
\hline & (Levels) & (1st Differences) & (Levels) & (1st Differences) \\
\hline & \multicolumn{4}{|c|}{$\begin{array}{c}\text { Summary Statistics } \\
\end{array}$} \\
\hline Mean & -0.717 & 0.000 & -1.375 & 0.000 \\
\hline Median & -0.650 & 0.000 & -1.250 & 0.000 \\
\hline Maximum & -0.050 & 0.525 & -0.725 & 0.250 \\
\hline Minimum & -2.450 & -1.450 & -2.750 & -0.900 \\
\hline Std. Dev. & 0.357 & 0.144 & 0.440 & 0.071 \\
\hline Skewness & -1.137 & -1.693 & -0.595 & -3.169 \\
\hline \multirow[t]{2}{*}{ Kurtosis } & 4.826 & 19.921 & 2.439 & 41.925 \\
\hline & \multicolumn{4}{|c|}{ Unit Root Tests } \\
\hline Aug. Dickey-Fuller & $-4.763 * * *$ & $-30.984 * * *$ & -2.159 & $-26.808 * * *$ \\
\hline Phillips-Perron & $-5.436 * * *$ & $-31.203 * * *$ & -2.216 & $-26.815^{* * *}$ \\
\hline Observations & 715 & 715 & 715 & 715 \\
\hline
\end{tabular}

Note: $3 / 18 / 2004$ to $12 / 29 / 2006$ sample period. Unit root test $10 \%, 5 \%$, and $1 \%$ critical values for 1 -month are $2.568888,-2.865412$, and -3.439371 respectively. Unit root test $10 \%, 5 \%$, and $1 \%$ critical values for 1 -year are $2.568864,-2.865366$, and -3.439268 . $* * *$, and $* * *$ indicate coefficients significant at $10 \%, 5 \%$, and $1 \%$ level respectively. 
Table 2: Regression results for significant macroeconomic announcement surprises on risk reversals

\begin{tabular}{|c|c|c|c|c|}
\hline \multirow{2}{*}{$\begin{array}{l}\text { ALL Macro Surprises } \\
\text { U.S. Announcements }\end{array}$} & \multicolumn{2}{|c|}{ Baseline(1) } & \multicolumn{2}{|c|}{ Baseline (2) } \\
\hline & Coef. & S.E. & Coef. & S.E. \\
\hline GDP & $-5.517 * *$ & $(2.653)$ & $-4.259 * *$ & $(1.768)$ \\
\hline Nonfarm payroll empoloyment & $4.679 *$ & $(2.468)$ & 0.616 & $(2.314)$ \\
\hline Consumer credit & $-4.293 *$ & $(2.550)$ & $-4.858 *$ & $(2.619)$ \\
\hline Japanese Announcements & Coef. & S.E. & Coef. & S.E. \\
\hline Trade balance & $-5.553 *$ & $(2.857)$ & $-5.452 * *$ & $(2.796)$ \\
\hline Consumer confidence index & $3.660 * *$ & $(1.865)$ & $3.517 *$ & $(1.859)$ \\
\hline Overall household spending & $5.738 * *$ & $(2.485)$ & $5.558 * * *$ & $(1.530)$ \\
\hline Exchange rate & & & $5.239 * * *$ & $(1.256)$ \\
\hline Interest rate differential & & & $-0.067 *$ & $(0.041)$ \\
\hline Lag dependent variable & 0.008 & $(0.052)$ & 0.003 & $(0.044)$ \\
\hline R-squared & 0.033 & & 0.211 & \\
\hline Durbin-Watson & 1.814 & & 2.085 & \\
\hline Akaike info crite rion & -2.402 & & -2.600 & \\
\hline
\end{tabular}

Note: 3/18/2004 12/29/2006 sample, 715 observations. Standard errors in parentheses; *, **, and *** indicate coefficients significant at $10 \%, 5 \%$, and $1 \%$ level respectively. Constant and day of the week omitted because of insignificant coefficient. Only coefficient on significant macroeconomic surprise announcements reported, for complete regression results see Table $\mathrm{A} 1$ in the appendix.

Table 3: Regression results of significant LARGE macroeconomic announcement surprises on risk reversals

\begin{tabular}{|c|c|c|c|c|c|c|c|c|}
\hline \multirow{3}{*}{$\begin{array}{c}\text { LARGE Macro Surprises } \\
\text { U.S. Announcements } \\
\end{array}$} & \multicolumn{4}{|c|}{ Baseline(2) } & \multicolumn{4}{|c|}{$\operatorname{ARMA}(\mathbf{4 , 4 )}$} \\
\hline & \multicolumn{2}{|c|}{ Narrow Bounds } & \multicolumn{2}{|c|}{ Wide Bounds } & \multicolumn{2}{|c|}{ Narrow Bounds } & \multicolumn{2}{|c|}{ Wide Bounds } \\
\hline & Coef. & S.E. & Coef. & S.E. & Coef. & S.E. & Coef. & S.E. \\
\hline GDP & $-4.219 * *$ & $(1.747)$ & $-3.557 *$ & $(2.043)$ & $-4.327 * *$ & $(1.841)$ & $-3.959 * *$ & $(1.982)$ \\
\hline Personal income & 1.658 & $(1.293)$ & $1.082 * *$ & $(0.421)$ & 1.569 & $(1.168)$ & $1.211 * * *$ & $(0.374)$ \\
\hline Consumer credit & $-4.873 *$ & $(2.635)$ & $-6.478 *$ & $(3.441)$ & $-5.518 * *$ & $(2.726)$ & $-7.033 * *$ & $(3.567)$ \\
\hline Japanese Announcements & Coef. & S.E. & Coef. & S.E. & Coef. & S.E. & Coef. & S.E. \\
\hline Trade balance & $-5.526 * *$ & $(2.793)$ & $-6.396 *$ & $(3.448)$ & $-5.620 * *$ & $(2.788)$ & $-6.436 *$ & $(3.512)$ \\
\hline Consumer confidence index & $3.513 *$ & $(1.855)$ & 1.812 & $(1.569)$ & $3.538 *$ & $(1.939)$ & 1.680 & $(1.765)$ \\
\hline TANKAN non-manuf. index & -1.946 & (3.904) & $-3.702 *$ & $(2.100)$ & -2.765 & $(3.764)$ & $-3.017 *$ & $(1.658)$ \\
\hline Overall household spending & $5.583 * * *$ & $(1.478)$ & $4.389 * * *$ & $(0.928)$ & $5.903 * * *$ & $(1.948)$ & $4.794 * * *$ & $(1.573)$ \\
\hline Exchange rate & $5.237 * * *$ & $(1.256)$ & $5.193 * * *$ & $(1.249)$ & $4.593 * * *$ & $(0.705)$ & $4.539 * * *$ & $(0.691)$ \\
\hline Interest rate differential & $-0.068 *$ & $(0.041)$ & -0.065 & $(0.041)$ & $-0.076 * *$ & $(0.037)$ & $-0.074 * *$ & $(0.037)$ \\
\hline Lag dependent variable & 0.003 & $(0.044)$ & 0.002 & $(0.045)$ & & & & \\
\hline $\operatorname{AR}(4)$ & & & & & $-0.658 * * *$ & $(0.164)$ & $-0.653 * * *$ & $(0.169)$ \\
\hline $\mathrm{MA}(4)$ & & & & & $0.726 * * *$ & $(0.148)$ & $0.724 * * *$ & $(0.152)$ \\
\hline R-squared & 0.212 & & 0.211 & & 0.286 & & 0.286 & \\
\hline Durbin-Watson & 2.084 & & 2.078 & & 2.129 & & 2.126 & \\
\hline Akaike info criterion & -2.600 & & -2.599 & & -2.696 & & -2.696 & \\
\hline
\end{tabular}

Note: 3/18/2004 12/29/2006 sample, 715 observations. Standard errors in parentheses; *, **, and *** indicate coefficients significant at $10 \%, 5 \%$, and $1 \%$ level respectively. Constant and day of the week omitted because of insignificant coefficient. Only coefficient on significant macroeconomic surprise announcements reported, for complete regression results see Table A2 in the appendix. 
Table 4: Regression results of significant LARGE macroeconomic surprise announcements conditional on increasing risk of sharp yen appreciation

\begin{tabular}{|c|c|c|c|c|}
\hline \multirow{3}{*}{$\begin{array}{c}\text { LARGE Macro Surprises } \\
\text { U.S. Announcements }\end{array}$} & \multicolumn{4}{|c|}{$\operatorname{ARMA}(4,4)$} \\
\hline & \multicolumn{2}{|c|}{ Narrow Bounds } & \multicolumn{2}{|c|}{ Wide Bounds } \\
\hline & Coef. & S.E. & Coef. & S.E. \\
\hline Capacity utilization & $10.679 * *$ & $(5.199)$ & $8.407 * *$ & $(3.549)$ \\
\hline Personal income & 1.126 & $(0.867)$ & $1.046 * * *$ & $(0.349)$ \\
\hline Consumer credit & -5.076 & $(10.597)$ & $-26.313 * * *$ & $(2.157)$ \\
\hline New home sales & -2.690 & $(1.903)$ & $-1.290 *$ & $(0.742)$ \\
\hline Trade balance & 5.558 & $(6.012)$ & $11.443 * * *$ & $(2.736)$ \\
\hline Consumer price index & 2.762 & $(5.401)$ & $-8.416 * * *$ & $(1.208)$ \\
\hline Housing starts & $7.819 * *$ & $(3.871)$ & $9.241 * *$ & $(4.276)$ \\
\hline Index of leading indicators & 1.432 & $(10.992)$ & $-10.328 * *$ & $(4.480)$ \\
\hline Japanese Announcements & Coef. & S.E. & Coef. & S.E. \\
\hline Trade balance & -8.472 & $(10.264)$ & $-20.050 * * *$ & $(0.998)$ \\
\hline Leading economic index & $-9.856 *$ & $(5.380)$ & - & - \\
\hline TANKAN large manufacturing index & -3.593 & $(5.969)$ & $3.060 * *$ & $(1.286)$ \\
\hline GDP (quarterly) & $-13.323 * * *$ & $(5.117)$ & - & - \\
\hline Construction orders & 3.788 & (3.257) & $6.030 * * *$ & $(1.224)$ \\
\hline Retail trade & $-12.474 * * *$ & $(3.797)$ & $-9.351 * * *$ & $(0.776)$ \\
\hline Consumer price index & -0.669 & $(4.440)$ & $-10.530 *$ & $(6.064)$ \\
\hline Overall household spending & $10.630 * *$ & $(5.148)$ & 4.097 & $(4.127)$ \\
\hline Exchange rate & $4.479 * * *$ & $(0.659)$ & $4.443 * * *$ & $(0.695)$ \\
\hline Interest rate differential & $-0.062 *$ & $(0.034)$ & $-0.065 *$ & $(0.034)$ \\
\hline $\operatorname{AR}(4)$ & $-0.647 * * *$ & $(0.164)$ & $-0.648 * * *$ & $(0.161)$ \\
\hline $\mathrm{MA}(4)$ & $0.728 * * *$ & $(0.144)$ & $0.728 * * *$ & $(0.142)$ \\
\hline R-squared & 0.287 & & 0.290 & \\
\hline Durbin-Watson & 2.189 & & 2.160 & \\
\hline Akaike info crite rion & -2.701 & & -2.730 & \\
\hline
\end{tabular}

Notes: All news announcement surprises have been interacted with a lagged dummy variable that takes on a value of 1 if the cost of hedging against sharp yen appreciation rose between day $t$ and $t-1.3 / 18 / 2004$ 12/29/2006 sample period, 715 observations. Standard errors in parentheses; *,**, and *** indicate coefficients significant at 10\%, 5\%, and $1 \%$ level respectively. Constant and day of the week omitted because of insignificant coefficient. Only coefficient on significant macroeconomic surprise announcements reported, for complete regression results see Table A3 in the appendix. 
Table5: Impact of significant news surprises on the value of 1-year risk reversals

\begin{tabular}{|c|c|c|c|c|}
\hline \multirow[b]{2}{*}{ Surprise Announcement } & \multicolumn{2}{|c|}{ 01/07/2005-03/13/2006 } & \multicolumn{2}{|c|}{$04 / 12 / 2006-05 / 17 / 2006$} \\
\hline & $\underline{\text { Narrow Bands }}$ & Wide Bands & $\underline{\text { Narrow Bands }}$ & Wide Bands \\
\hline US GDP & 0.096 & 0.070 & 0.000 & 0.000 \\
\hline US Personal income & 0.000 & 0.014 & 0.000 & 0.000 \\
\hline US Consumer credit & 0.198 & 0.143 & 0.009 & 0.000 \\
\hline JP Trade balance & 0.091 & 0.106 & -0.058 & -0.058 \\
\hline JP Consumer confidence index & -0.012 & 0.000 & -0.009 & 0.000 \\
\hline TANKAN non-manufacturing index & 0.000 & -0.016 & 0.000 & 0.000 \\
\hline JP Overall household spending & 0.000 & 0.000 & -0.029 & -0.024 \\
\hline Total & 0.373 & 0.317 & -0.088 & -0.081 \\
\hline$\%$ of Change in 1-Year Risk Reversal & $29.84 \%$ & $25.34 \%$ & $9.24 \%$ & $8.56 \%$ \\
\hline
\end{tabular}

Note: The impact is calculated by multiplying the standardized value of the news surprise component relative to the Bloomberg survey of market expectation by the regression coefficient. The bottom row reports the cumulative impact of news surprises during each subsample period as a percentage of change in the value of 1-year risk reversal during the same time period.

Table 6: Granger causality tests between risk-reversals and net non-commercial short positions (\% O.I.)

\begin{tabular}{|c|c|c|c|c|c|c|c|c|}
\hline & \multicolumn{4}{|c|}{ Baseline } & \multicolumn{4}{|c|}{ Controlling for exhange rate } \\
\hline & \multicolumn{2}{|c|}{ 1-lag } & \multicolumn{2}{|c|}{ 2-lag } & \multicolumn{2}{|c|}{ 1-lag } & \multicolumn{2}{|c|}{ 2-lag } \\
\hline & $\begin{array}{c}\text { risk } \\
\text { rersals } \\
\text { cause } \\
\text { positions }\end{array}$ & $\begin{array}{l}\text { positions } \\
\text { cause risk } \\
\text { reversals }\end{array}$ & $\begin{array}{c}\text { risk } \\
\text { rersals } \\
\text { cause } \\
\text { positions }\end{array}$ & $\begin{array}{l}\text { positions } \\
\text { cause risk } \\
\text { reversals }\end{array}$ & $\begin{array}{c}\text { risk } \\
\text { rersals } \\
\text { cause } \\
\text { positions }\end{array}$ & $\begin{array}{l}\text { positions } \\
\text { cause risk } \\
\text { reversals }\end{array}$ & $\begin{array}{c}\text { risk } \\
\text { rersals } \\
\text { cause } \\
\text { positions }\end{array}$ & $\begin{array}{l}\text { positions } \\
\text { cause risk } \\
\text { reversals }\end{array}$ \\
\hline \multicolumn{9}{|c|}{ 1-Month Risk Reversals } \\
\hline F-Statistic & $3.837 * *$ & 0.483 & $8.832 * * *$ & 2.213 & $4.326 * *$ & 0.362 & $8.374 * * *$ & 1.409 \\
\hline Probability & 0.052 & 0.488 & 0.000 & 0.113 & 0.039 & 0.548 & 0.000 & 0.248 \\
\hline Coeff. Sum & 6.042 & 0.002 & 21.439 & 0.000 & 7.683 & 0.002 & 24.116 & 0.004 \\
\hline Obs. & 146 & & 143 & & 146 & & 143 & \\
\hline \multicolumn{9}{|c|}{ 1-Year Risk Reversals } \\
\hline F-Statistic & $9.023 * * *$ & 0.521 & $9.611 * * *$ & $2.570 *$ & $7.720 * * *$ & 0.022 & $6.924 * * *$ & 1.798 \\
\hline Probability & 0.003 & 0.471 & 0.000 & 0.080 & 0.006 & 0.882 & 0.001 & 0.169 \\
\hline Coeff. Sum & 14.491 & 0.001 & 29.964 & -0.003 & 15.495 & 0.000 & 30.388 & -0.005 \\
\hline Obs. & 151 & & 150 & & 151 & & 150 & \\
\hline
\end{tabular}

Note: *,**, and *** indicate the null hypothesis of no Granger-causality is rejected at significant at $10 \%, 5 \%$, and $1 \%$ level respectively. 
Table 7: Approximate cumulative impact of macro surprises on CME net non-commercial futures short positions through Risk Reversal valuation.

\begin{tabular}{|c|c|c|c|c|}
\hline \multirow{2}{*}{$\begin{array}{l}\text { Subsample Period: } \\
\text { Calculation Method: }\end{array}$} & \multicolumn{2}{|c|}{ 01/07/2005-03/13/2006 } & \multicolumn{2}{|c|}{ 04/12/2006-05/17/2006 } \\
\hline & $\begin{array}{l}\text { Wide Bounds } \\
\text { 1-Lag Coeff. }\end{array}$ & $\begin{array}{c}\text { Narrow Bounds } \\
\text { 2-Lag Coeff. }\end{array}$ & $\begin{array}{c}\text { Wide Bounds } \\
\text { 1-Lag Coeff. }\end{array}$ & $\begin{array}{c}\text { Narrow Bounds } \\
\text { 2-Lag Coeff. }\end{array}$ \\
\hline Surprise Announcement & $\triangle \mathrm{NCMS}(\%$ O.I $)$ & $\Delta \mathrm{NCMS}(\%$ O.I $)$ & $\underline{\Delta N C M S}(\% \quad 0 . I)$ & $\triangle N C M S(\%$ O.I $)$ \\
\hline US GDP & 1.08 & 2.92 & 0.00 & 0.00 \\
\hline US Personal income & 0.22 & 0.00 & 0.00 & 0.00 \\
\hline US Consumer credit & 2.22 & 6.01 & 0.00 & 0.27 \\
\hline JP Trade balance & 1.64 & 2.76 & -0.89 & -1.77 \\
\hline JP Consumer confidence index & 0.00 & -0.37 & 0.00 & -0.28 \\
\hline TANKAN non-manufacturing index & -0.25 & 0.00 & 0.00 & 0.00 \\
\hline JP Overall household spending & 0.00 & 0.00 & -0.37 & -0.89 \\
\hline Total & 4.91 & 11.33 & -1.26 & -2.67 \\
\hline$\%$ of Total $\Delta$ NCMS(\% O.I.) & $16.47 \%$ & $38.03 \%$ & $4.79 \%$ & $10.14 \%$ \\
\hline
\end{tabular}

Note: The table shows the estimated cumulative impact over the sample period of macroeconomic news surprises on net non-commercial short positions (NCMS) as a percentage of total open interest (\% O.I.) on the Chicago

Mercantile Exchange (CME). The impact is calculated by multiplying the cumulative impact of news surprises on risk-reversals by the Granger-causality coefficients of risk-reversals on NCMS (\% O.I). 
Figure 1: U.S.-Japan interest rate differential and JPY/USD exchange rate.

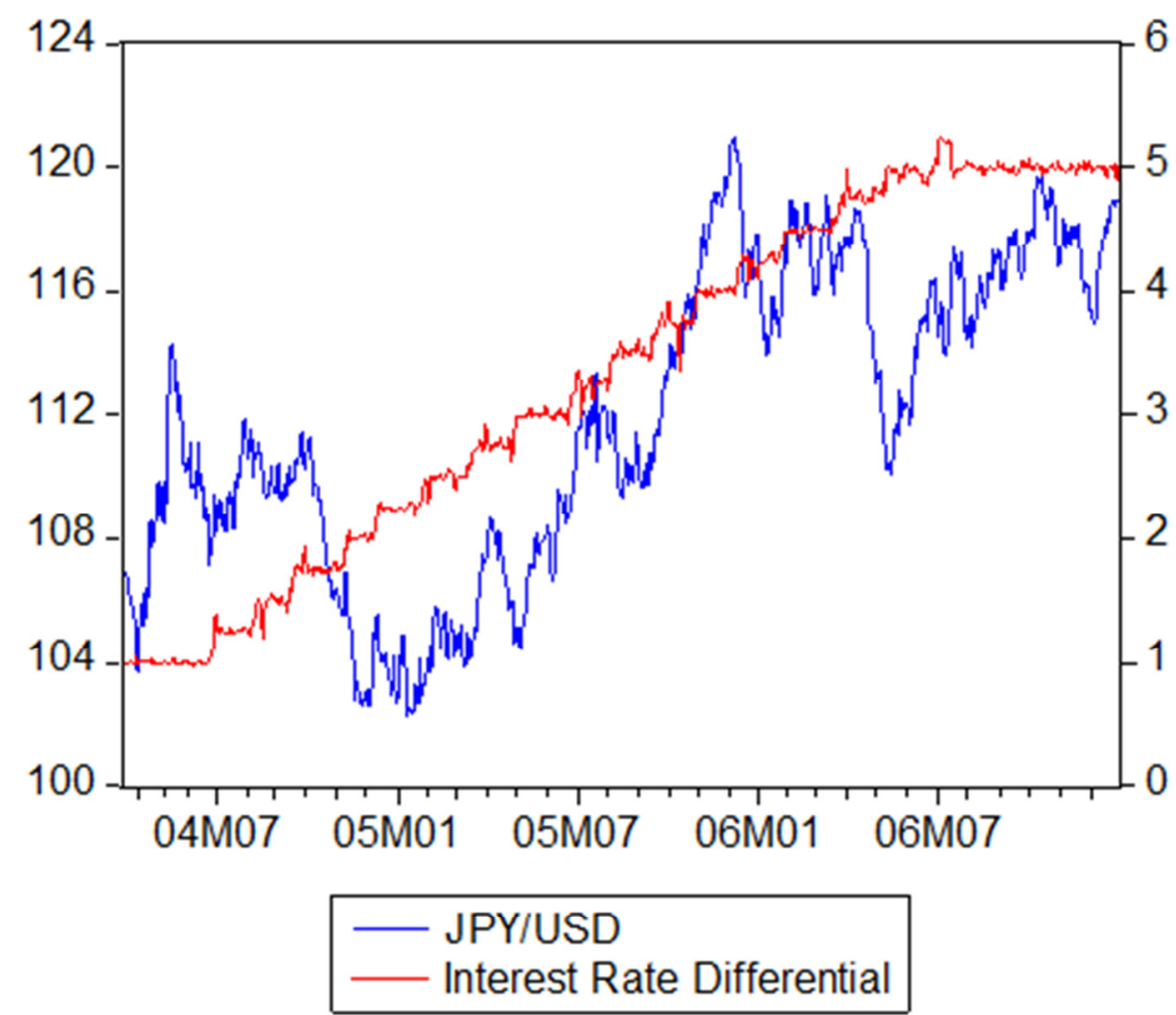

Note: An appreciation of the high yield currency is an example of the forward premium puzzle and the violation of the uncovered interest parity (UIP). The UIP regression coefficient has been estimated as low as -2.79 for the yen (Ichiue and Koyama , 2011). 
Figure 2: Impact of macroeconomic surprises on JPY/USD implied volatility smirk.

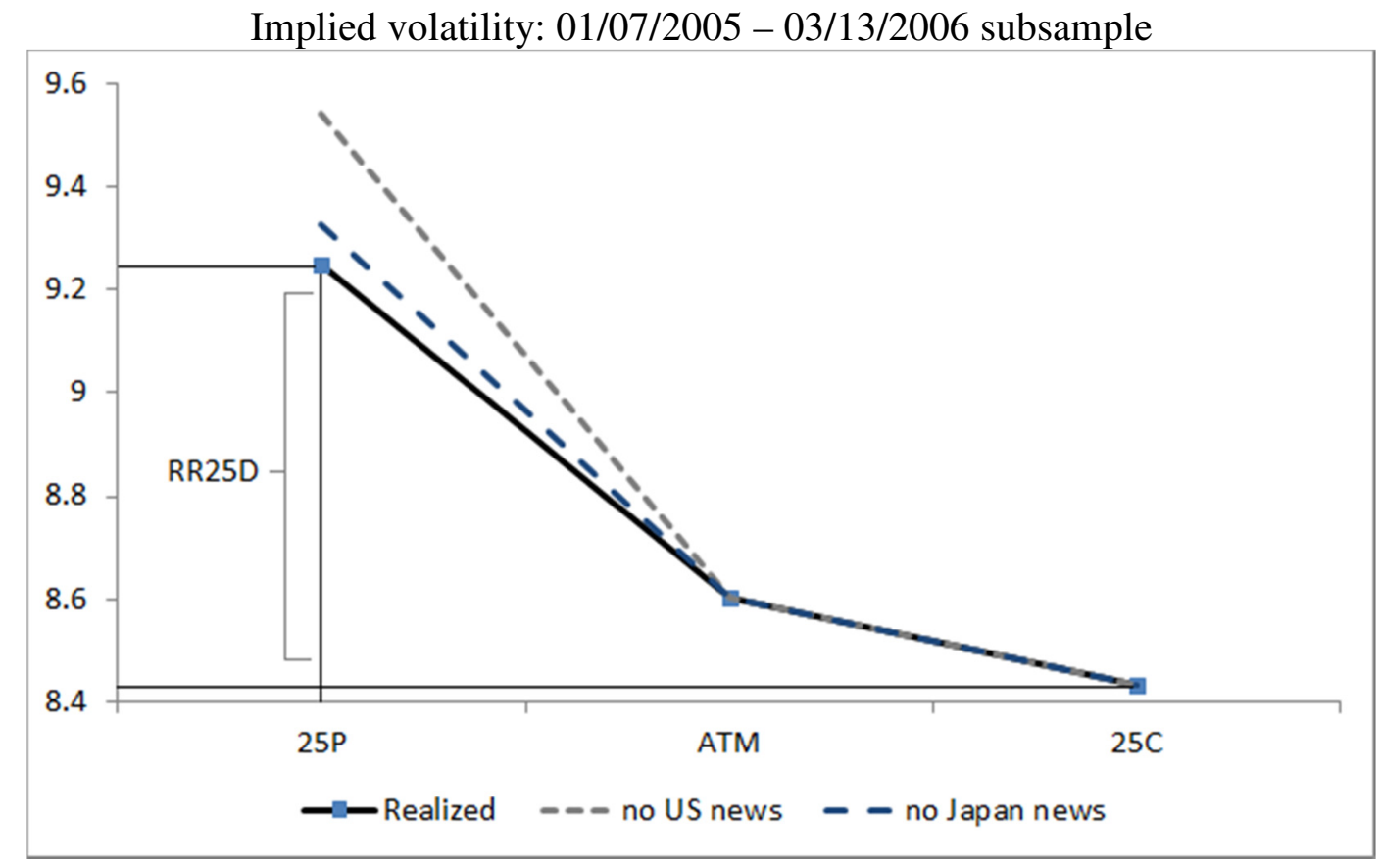

Implied volatility: 04/12/2006 - 05/17/2006 subsample

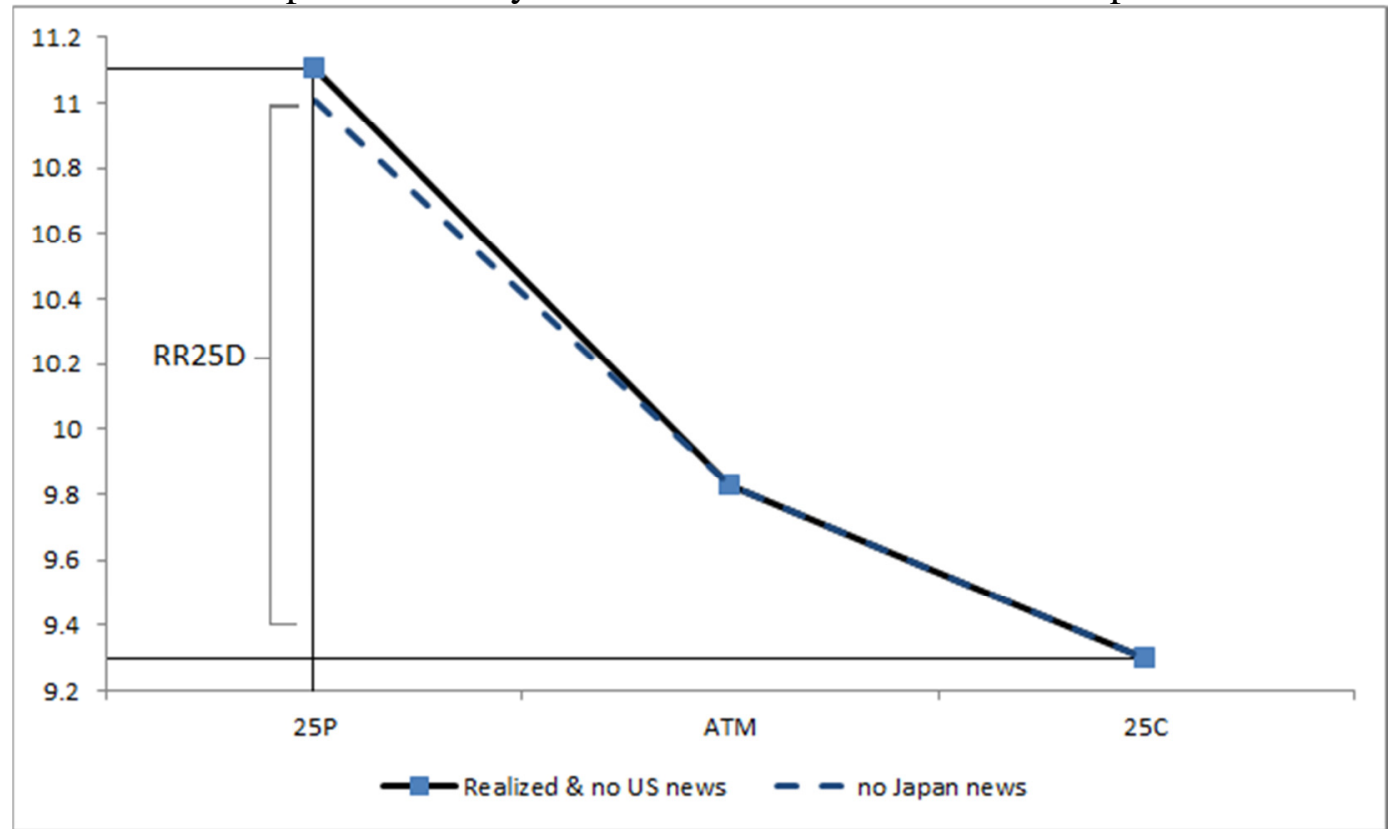

Notes: Implied volatility smirk means yen calls/dollar puts are more expensive. The vertical distance indicates the absolute value of 25-delta risk reversal: $R R^{25 \delta}=\sigma_{c}^{25 \delta}-\sigma_{p}^{25 \delta}$. Estimates of the shift in the implied volatility curve are based on results in Table 5. (Source: Bloomberg, authors' calculations) 
Figure 3: Carry trade return and total CME non-commercial short positions.

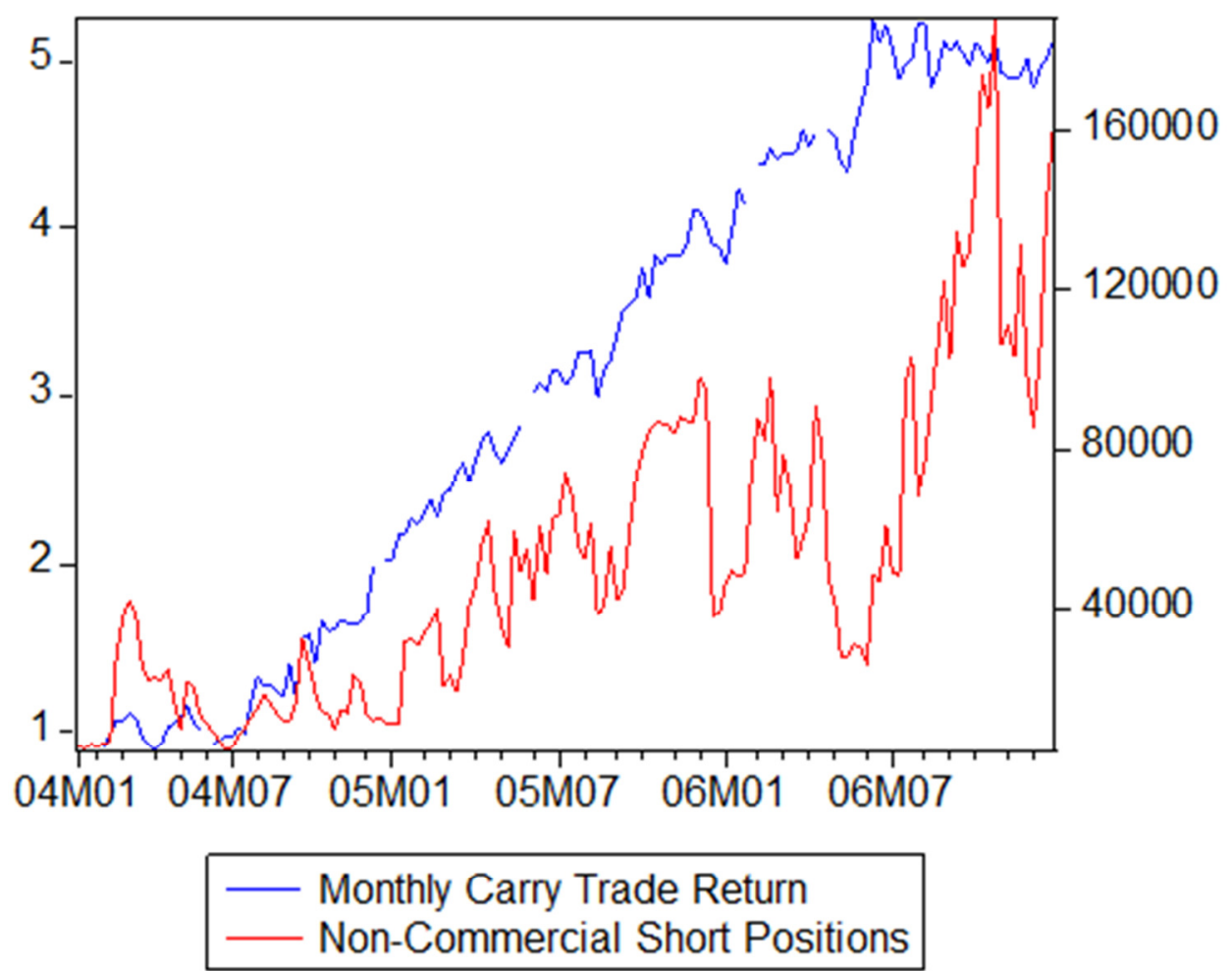

Note: We calculate carry trade return as $C R_{t+k}=\left(1+i_{k, t}^{U S}\right) S_{t+k} / S_{t}-\left(1+i_{k, t}^{J P}\right)$ where $i k, t$ denote the effective k-period deposit rates available in Japan and U.S. at time $t$. CFTC classifies traders as non-commercial if they have no foreign exchange exposure to hedge. A position corresponds to a contract value of 2.5 million yen (CFTC Explanatory Notes, http://www.cftc.gov/). 
Figure 4: Risk reversals and CME net non-commercial Yen short futures positions.

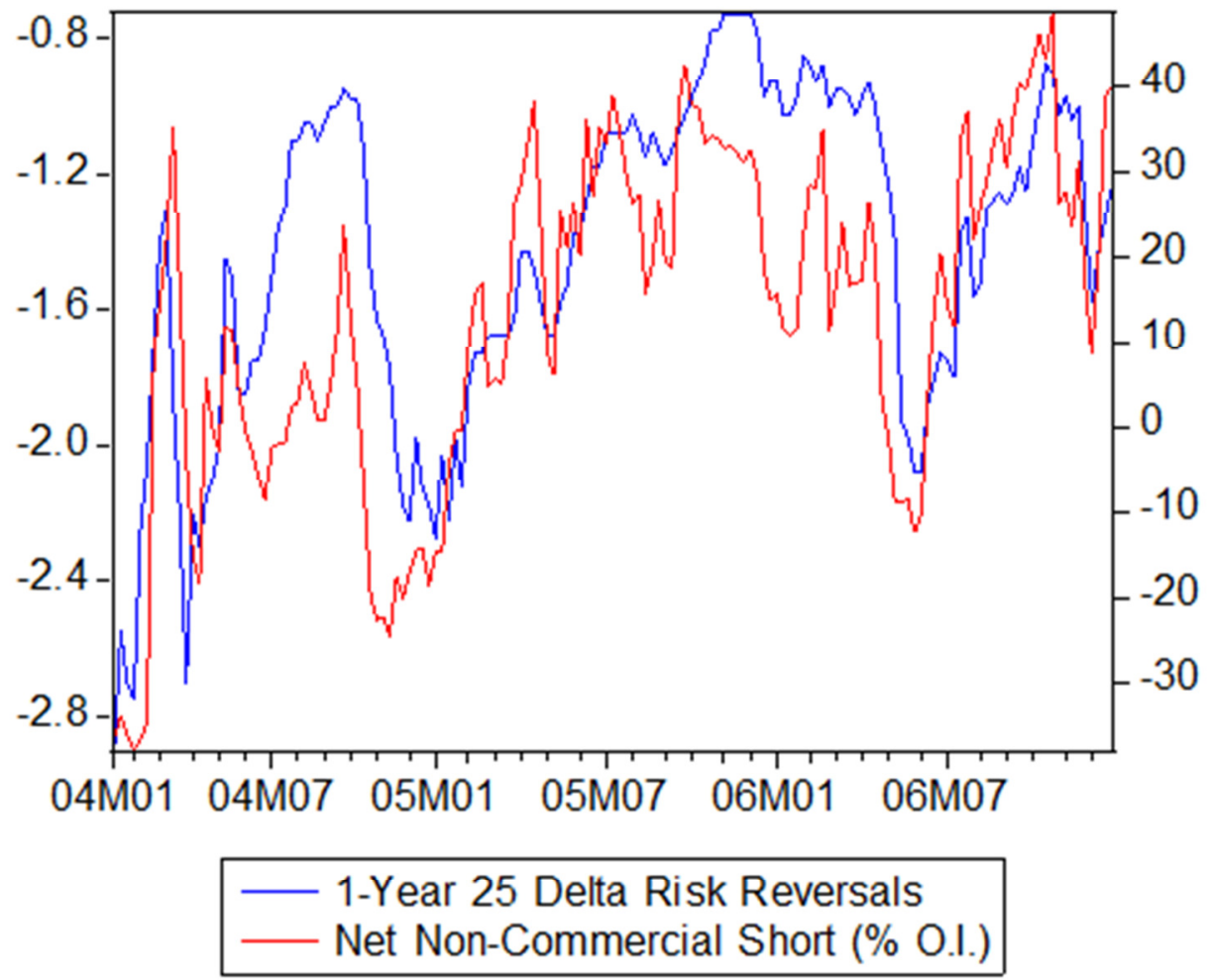

Notes: We construct the measure of CME net non-commercial short positions (NCMS) as a percentage of open interest (\% O.I.) by subtracting non-commercial long from non-commercial short positions divided by total open interest in yen futures. 
Appendix: complete coefficient vector - impact of macroeconomic surprises on risk reversals Table 1A: Regression results of ALL macroeconomic announcement surprises

\begin{tabular}{|c|c|c|c|c|}
\hline \multirow{2}{*}{$\begin{array}{c}\text { ALL Macro Surprises } \\
\text { U.S. Announcements }\end{array}$} & \multicolumn{2}{|c|}{ Baseline(1) } & \multicolumn{2}{|c|}{ Baseline (2) } \\
\hline & Coef. & S.E. & Coef. & S.E. \\
\hline GDP & $-5.517 * *$ & $(2.653)$ & $-4.259 * *$ & (1.768) \\
\hline Nonfarm payroll empoloyment & $4.679 *$ & $(2.468)$ & 0.616 & $(2.314)$ \\
\hline Industrial production & -2.341 & $(3.396)$ & -2.679 & $(3.154)$ \\
\hline Capacity utilization & -0.970 & $(3.025)$ & -1.853 & (3.034) \\
\hline Personal income & 0.766 & $(1.507)$ & 1.661 & $(1.295)$ \\
\hline Consumer credit & $-4.293 *$ & $(2.550)$ & $-4.858 *$ & $(2.619)$ \\
\hline Consumer spending & -1.961 & $(3.582)$ & -2.553 & (3.604) \\
\hline New home sales & 0.840 & $(2.728)$ & 1.669 & $(2.473)$ \\
\hline Durable goods orders & 0.084 & $(2.387)$ & 1.240 & $(2.567)$ \\
\hline Factory orders & 1.353 & $(1.650)$ & -1.471 & (1.607) \\
\hline Business inventories & 3.646 & $(2.673)$ & 1.781 & $(2.277)$ \\
\hline Trade balance & 0.175 & $(3.476)$ & -2.756 & $(2.406)$ \\
\hline Producer price index & -2.826 & $(3.080)$ & -2.867 & $(2.720)$ \\
\hline Consumer price index & -1.654 & $(4.822)$ & -0.687 & $(4.003)$ \\
\hline Consumer confidence index & 2.241 & $(3.747)$ & 0.317 & $(3.788)$ \\
\hline NAPM index & 2.181 & $(1.975)$ & -0.096 & $(2.271)$ \\
\hline Housing starts & -0.040 & $(2.218)$ & -0.703 & $(2.123)$ \\
\hline Index of leading indicators & -2.248 & $(7.118)$ & -0.775 & $(4.959)$ \\
\hline Japanese Announcements & Coef. & S.E. & Coef. & S.E. \\
\hline Trade balance & $-5.553 *$ & $(2.857)$ & $-5.452 * *$ & $(2.796)$ \\
\hline Current account & -1.648 & $(1.782)$ & -0.632 & $(1.760)$ \\
\hline Leading economic index & 2.220 & $(1.982)$ & 0.752 & $(1.626)$ \\
\hline Consumer confidence index & $3.660 * *$ & $(1.865)$ & $3.517 *$ & $(1.859)$ \\
\hline TANKAN large manufacturing index & 0.317 & (3.915) & 4.810 & (3.647) \\
\hline TANKAN non-manufacturing index & 2.639 & $(5.011)$ & -2.026 & $(3.856)$ \\
\hline Monetary base & -2.744 & $(4.125)$ & -2.265 & (4.115) \\
\hline Capacity utilization & -7.503 & $(13.797)$ & -5.090 & (9.934) \\
\hline GDP (quarterly) & -2.258 & $(3.118)$ & -3.249 & $(2.366)$ \\
\hline Large retail sales & -5.532 & $(3.595)$ & -5.086 & (3.388) \\
\hline Construction orders & -0.019 & $(1.150)$ & 1.326 & $(1.858)$ \\
\hline Industrial production & 0.434 & $(2.123)$ & 1.683 & $(2.367)$ \\
\hline Retail trade & 0.386 & $(3.218)$ & 0.097 & (3.309) \\
\hline Consumer price index & -3.304 & $(2.229)$ & 0.158 & $(2.951)$ \\
\hline Overall household spending & $5.738 * *$ & $(2.485)$ & $5.558 * * *$ & $(1.530)$ \\
\hline Exchange rate & & & $5.239 * * *$ & $(1.256)$ \\
\hline Interest rate differential & & & $-0.067 *$ & $(0.041)$ \\
\hline Lag dependent variable & 0.008 & $(0.052)$ & 0.003 & $(0.044)$ \\
\hline R-s quared & 0.033 & & 0.211 & \\
\hline Durbin-Wats on & 1.814 & & 2.085 & \\
\hline Akaike info crite rion & -2.402 & & -2.600 & \\
\hline
\end{tabular}

Note: 3/18/2004 12/29/2006 sample, 715 observations. Standard errors in parentheses; *, **, and *** indicate coefficients significant at $10 \%, 5 \%$, and $1 \%$ level respectively. Constant and day of the week omitted because of insignificant coefficient. 
Table A2: Regression results of LARGE macroeconomic announcement surprises

\begin{tabular}{|c|c|c|c|c|c|c|c|c|}
\hline \multirow{3}{*}{$\begin{array}{c}\text { LARGE Macro Surprises } \\
\text { U.S. Announcements }\end{array}$} & \multicolumn{4}{|c|}{$\begin{array}{l}\text { Baseline(2) } \\
\end{array}$} & \multicolumn{4}{|c|}{ ARMA $(4,4)$} \\
\hline & \multicolumn{2}{|c|}{ Narrow Bounds } & \multicolumn{2}{|c|}{ Wide Bounds } & \multicolumn{2}{|c|}{ Narrow Bounds } & \multicolumn{2}{|c|}{ Wide Bounds } \\
\hline & Coef. & S.E. & Coef. & S.E. & Coef. & S.E. & Coef. & S.E. \\
\hline GDP & $-4.219 * *$ & $(1.747)$ & $-3.557 *$ & $(2.043)$ & $-4.327 * *$ & $(1.841)$ & $-3.959 * *$ & $(1.982)$ \\
\hline Nonfarm payroll empl. & 0.661 & (2.317) & 1.663 & (2.388) & 0.583 & $(2.110)$ & 1.567 & $(2.214)$ \\
\hline Industrial production & -2.744 & $(3.166)$ & 0.354 & $(5.383)$ & -2.517 & (3.244) & 0.897 & $(5.315)$ \\
\hline Capacity utilization & -1.784 & (3.024) & -3.847 & $(5.701)$ & -1.289 & $(3.041)$ & -3.186 & $(5.544)$ \\
\hline Personal income & 1.658 & $(1.293)$ & $1.082 * *$ & $(0.421)$ & 1.569 & $(1.168)$ & $1.211 * * *$ & $(0.374)$ \\
\hline Consumer credit & $-4.873 *$ & $(2.635)$ & $-6.478 *$ & $(3.441)$ & $-5.518 * *$ & $(2.726)$ & $-7.033 * *$ & $(3.567)$ \\
\hline Consumer spending & -2.522 & (3.603) & -2.284 & (4.088) & -2.289 & (3.257) & -2.430 & (3.688) \\
\hline New home sales & 1.620 & $(2.481)$ & 2.850 & (2.617) & 0.666 & (2.539) & 2.717 & $(2.582)$ \\
\hline Durable goods orders & 1.190 & $(2.576)$ & 1.221 & $(1.842)$ & 0.788 & $(2.485)$ & 1.511 & $(1.751)$ \\
\hline Factory orders & -1.488 & (1.612) & -1.512 & $(1.567)$ & -0.900 & (1.509) & -0.762 & $(1.461)$ \\
\hline Business inventories & 1.786 & $(2.278)$ & 1.949 & (2.844) & 1.613 & $(2.245)$ & 1.781 & $(2.788)$ \\
\hline Trade balance & -2.850 & $(2.396)$ & -1.254 & $(2.825)$ & -1.924 & (2.379) & -0.069 & $(2.867)$ \\
\hline Producer price index & -3.049 & $(2.771)$ & -0.751 & $(1.060)$ & -2.227 & $(2.164)$ & -0.659 & $(1.010)$ \\
\hline Consumer price index & -0.717 & (4.008) & 1.308 & $(3.540)$ & -0.263 & $(4.031)$ & 1.826 & (3.593) \\
\hline Consumer confidence index & 0.406 & $(3.800)$ & 1.052 & $(4.317)$ & 1.149 & $(3.635)$ & 0.139 & $(4.335)$ \\
\hline NAPM index & -0.064 & $(2.263)$ & -0.456 & $(2.179)$ & 0.163 & $(2.169)$ & -0.399 & $(2.067)$ \\
\hline Housing starts & -0.612 & $(2.127)$ & 0.602 & $(2.020)$ & -0.936 & $(2.262)$ & 0.244 & $(2.179)$ \\
\hline Index of leading indicators & -0.774 & (4.958) & -4.849 & $(3.602)$ & -2.628 & (3.934) & -5.116 & $(3.891)$ \\
\hline Japanese Announcements & Coef. & S.E. & Coef. & S.E. & Coef. & S.E. & Coef. & S.E. \\
\hline Trade balance & $-5.526 * *$ & $(2.793)$ & $-6.396 *$ & $(3.448)$ & $-5.620 * *$ & $(2.788)$ & $-6.436 *$ & $(3.512)$ \\
\hline Current account & -0.622 & $(1.774)$ & -0.762 & $(1.951)$ & -0.696 & $(1.716)$ & -0.868 & $(1.916)$ \\
\hline Leading economic index & 0.758 & (1.634) & 0.393 & $(1.753)$ & 0.303 & $(1.723)$ & -0.322 & $(1.762)$ \\
\hline Consumer confidence index & $3.513 *$ & $(1.855)$ & 1.812 & $(1.569)$ & $3.538 *$ & (1.939) & 1.680 & $(1.765)$ \\
\hline TANKAN large manuf. index & 4.823 & $(3.650)$ & 4.440 & $(4.463)$ & 3.874 & (3.346) & 3.640 & $(3.857)$ \\
\hline TANKAN non-manuf. index & -1.946 & (3.904) & $-3.702 *$ & $(2.100)$ & -2.765 & $(3.764)$ & $-3.017 *$ & $(1.658)$ \\
\hline Monetary base & -2.209 & (4.111) & -2.144 & $(4.271)$ & -1.551 & $(3.607)$ & -1.062 & $(3.776)$ \\
\hline Capacity utilization & -4.751 & $(9.922)$ & -6.452 & $(8.678)$ & -7.923 & (10.476) & -10.506 & $(9.524)$ \\
\hline GDP (quarterly) & -3.205 & $(2.355)$ & -3.261 & $(2.410)$ & -2.948 & $(2.396)$ & -2.828 & $(2.480)$ \\
\hline Large retail sales & -5.197 & (3.399) & -5.197 & $(3.495)$ & -4.110 & (3.578) & -4.798 & (3.739) \\
\hline Construction orders & 1.365 & $(1.898)$ & 0.736 & $(2.112)$ & 1.321 & (1.698) & 1.007 & $(2.126)$ \\
\hline Industrial production & 1.565 & (2.379) & 0.987 & $(2.583)$ & 0.726 & $(2.205)$ & 0.648 & $(2.576)$ \\
\hline Retail trade & 0.064 & $(3.353)$ & 1.833 & $(3.692)$ & -0.102 & $(3.277)$ & 1.304 & $(3.672)$ \\
\hline Consumer price index & 0.114 & $(2.972)$ & 2.747 & $(3.460)$ & 0.644 & (2.616) & 2.765 & $(2.995)$ \\
\hline Overall household spending & $5.583 * * *$ & $(1.478)$ & $4.389 * * *$ & $(0.928)$ & $5.903 * * *$ & $(1.948)$ & $4.794 * * *$ & $(1.573)$ \\
\hline Exchange rate & $5.237 * * *$ & $(1.256)$ & $5.193 * * *$ & $(1.249)$ & 4.593 *** & $(0.705)$ & $4.539 * * *$ & $(0.691)$ \\
\hline Interest rate differential & $-0.068 *$ & $(0.041)$ & -0.065 & $(0.041)$ & $-0.076 * *$ & $(0.037)$ & $-0.074 * *$ & $(0.037)$ \\
\hline Lag dependent variable & 0.003 & $(0.044)$ & 0.002 & $(0.045)$ & & & & \\
\hline $\mathrm{AR}(4)$ & & & & & $-0.658 * * *$ & $(0.164)$ & $-0.653 * * *$ & $(0.169)$ \\
\hline $\mathrm{MA}(4)$ & & & & & 0.726 *** & $(0.148)$ & $0.724 * * *$ & $(0.152)$ \\
\hline R-squared & 0.212 & & 0.211 & & 0.286 & & 0.286 & \\
\hline Durbin-Wats on & 2.084 & & 2.078 & & 2.129 & & 2.126 & \\
\hline Akaike info criterion & -2.600 & & -2.599 & & -2.696 & & -2.696 & \\
\hline
\end{tabular}

Note: 3/18/2004 12/29/2006 sample, 715 observations. Standard errors in parentheses; *, **, and *** indicate coefficients significant at 10\%,5\%, and $1 \%$ level respectively. Constant and day of the week omitted because of insignificant coefficient. 
Table A3: Regression results of LARGE macroeconomic surprise announcements conditional on increasing risk of sharp yen appreciation

\begin{tabular}{|c|c|c|c|c|}
\hline \multirow[b]{3}{*}{ U.S. Announcements } & \multicolumn{4}{|c|}{$\operatorname{ARMA}(4,4)$} \\
\hline & \multicolumn{2}{|c|}{ Narrow Bounds } & \multicolumn{2}{|c|}{ Wide Bounds } \\
\hline & Coef. & S.E. & Coef. & S.E. \\
\hline GDP & -1.829 & $(3.887)$ & -6.944 & $(4.935)$ \\
\hline Nonfarm payroll empoloyment & -6.419 & $(8.050)$ & - & - \\
\hline Industrial production & 4.807 & $(3.080)$ & - & - \\
\hline Capacity utilization & $10.679 * *$ & $(5.199)$ & $8.407 * *$ & $(3.549)$ \\
\hline Personal income & 1.126 & $(0.867)$ & $1.046 * * *$ & $(0.349)$ \\
\hline Consumer credit & -5.076 & $(10.597)$ & $-26.313 * * *$ & $(2.157)$ \\
\hline Consumer spending & 9.139 & $(8.657)$ & - & - \\
\hline New home sales & -2.690 & $(1.903)$ & $-1.290 *$ & $(0.742)$ \\
\hline Durable goods orders & 0.620 & $(2.836)$ & 2.182 & $(3.035)$ \\
\hline Factory orders & 1.156 & $(3.350)$ & -0.596 & $(1.306)$ \\
\hline Business inventories & 5.263 & $(9.269)$ & - & - \\
\hline Trade balance & 5.558 & $(6.012)$ & $11.443 * * *$ & $(2.736)$ \\
\hline Producer price index & -5.381 & $(5.865)$ & -1.152 & $(1.263)$ \\
\hline Consumer price index & 2.762 & $(5.401)$ & $-8.416 * * *$ & $(1.208)$ \\
\hline Consumer confidence index & -4.303 & $(5.117)$ & -2.432 & (7.176) \\
\hline NAPM index & 5.185 & $(6.617)$ & -2.551 & $(5.271)$ \\
\hline Housing starts & $7.819 * *$ & $(3.871)$ & $9.241 * *$ & $(4.276)$ \\
\hline Index of leading indicators & 1.432 & $(10.992)$ & $-10.328 * *$ & $(4.480)$ \\
\hline Japanese Announcements & Coef. & S.E. & Coef. & S.E. \\
\hline Trade balance & -8.472 & $(10.264)$ & $-20.050 * * *$ & $(0.998)$ \\
\hline Current account & -6.551 & $(6.680)$ & - & - \\
\hline Leading economic index & $-9.856 *$ & $(5.380)$ & - & - \\
\hline Consumer confidence index & 5.028 & $(5.800)$ & 2.619 & $(3.428)$ \\
\hline TANKAN large manufacturing index & -3.593 & $(5.969)$ & $3.060 * *$ & $(1.286)$ \\
\hline TANKAN non-manufacturing index & -4.587 & $(16.470)$ & - & - \\
\hline Monetary base & 30.400 & $(21.217)$ & - & - \\
\hline Capacity utilization & - & - & - & - \\
\hline GDP (quarterly) & $-13.323 * * *$ & $(5.117)$ & - & - \\
\hline Large retail sales & -8.823 & $(8.179)$ & -15.629 & $(13.881)$ \\
\hline Construction orders & 3.788 & $(3.257)$ & $6.030 * * *$ & $(1.224)$ \\
\hline Industrial production & -5.762 & $(5.312)$ & -6.696 & $(5.504)$ \\
\hline Retail trade & $-12.474 * * *$ & $(3.797)$ & $-9.351 * * *$ & $(0.776)$ \\
\hline Consumer price index & -0.669 & $(4.440)$ & $-10.530 *$ & $(6.064)$ \\
\hline Overall household spending & $10.630 * *$ & $(5.148)$ & 4.097 & (4.127) \\
\hline Exchange rate & $4.479 * * *$ & $(0.659)$ & $4.443 * * *$ & $(0.695)$ \\
\hline Interest rate differential & $-0.062 *$ & $(0.034)$ & $-0.065 *$ & $(0.034)$ \\
\hline $\operatorname{AR}(4)$ & $-0.647 * * *$ & $(0.164)$ & $-0.648 * * *$ & $(0.161)$ \\
\hline MA(4) & $0.728 * * *$ & $(0.144)$ & $0.728 * * *$ & $(0.142)$ \\
\hline R-squared & 0.287 & & 0.290 & \\
\hline Durbin-Wats on & 2.189 & & 2.160 & \\
\hline Akaike info criterion & -2.701 & & -2.730 & \\
\hline
\end{tabular}

Notes: All news announcement surprises have been interacted with a lagged dummy variable that takes on a value of 1 if the cost of hedging against sharp yen appreciation rose between day $t$ and $t-1.3 / 18 / 2004$ 12/29/2006 sample period, 715 observations. Standard errors in parentheses; *, **, and *** indicate coefficients significant at 10\%, 5\%, and $1 \%$ level respectively. Constant and day of the week omitted because of insignificant coefficients. 